Trakya Eğitim Dergisi

Cilt 9, Sayı 3

Eylül 2019, 487-505

Geliş Tarihi: 19.09.2018

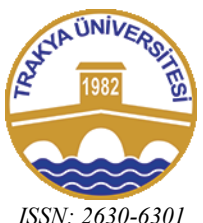

ISSN: 2630-6301
Trakya Journal of Education

Volume 9, Issue 3

September 2019, 487-505

Doi: $10.24315 /$ tred.461320

Yayına Kabul Tarihi: 25.05.2019

\title{
Özel Gereksinimli Çocuk Ebeveynlerinin Yaşamda Anlam Ve Kendilik Algılarının Psikolojik Dayanıklıklarıyla İlişkisi
}

\section{The Relation between Psychological Resilience with Meaning in Life a and Self Perception of Parents of Children with Special Needs}

\begin{abstract}
Aydan AYDIN ${ }^{1}$
Öz: $\mathrm{Bu}$ araştırmada özel gereksinimli çocuk ebeveynlerinin yaşamda anlamın varlığı ve yaşamda anlamın aranması ile ebeveyn rolüne ilişkin kendilik algılarının psikolojik dayanıklıkları ile iliş̧isinin incelenmesi amaçlanmıştır. Araştırmanın bağımlı değişkeni ile bağımsız değişkenleri arasındaki ilişkiyi belirlemek için hiyerarşik regresyon analizi kullanılmıştır. Araştırma İstanbul'da rehabilitasyon merkezlerine devam eden 406 özel gereksinimli çocuk ebeveyni ile gerçekleştirilmiştir. Araştırmada veri toplama araçları olarak Yaşamda Anlam Ölçeği (YAÖ), Ebeveyn Rolüne İlişkin Kendilik Algısı Ölçeği (ERKA) ile Yetişkinler İçin Psikolojik Dayanıklılık Ölçeği (PDÖ) kullanılmıştır. Araştırma sonucunda YAÖ yaşamda anlamın aranması, YAÖ yaşamda anlamın varlığı, ERKA rol doyumu ve ERKA rol dengelemesi ile PDÖ toplam puan arasındaki ilişkinin anlamlı olduğu sonucuna ulaşılmış, adı geçen bu değişkenlerin PDÖ toplam puanının toplam varyansının \%18'ini açıkladığı

Abstract: This research aims to investigate the relationship of these parents' psychological endurance to their perceptions about the existence of meaning in life, the search for meaning in life and their self perceptions about their parental roles. The participants of the study are 406 parents who have children with special education needs. The data collection instruments used in this study are the Meaning in Life Questionnaire (MLQ), Self-Perception of Parental Role (SPRR) and Endurance Scale for Adults (ESA). As a result of data analysis, it was found that there is a significant relationship between the total score of ESA and MLQ search for meaning in life, MLQ the existence of meaning in life, SPRR role satisfaction and SPRR role balance. It was revealed that these variables explain $18 \%$ total variance of the total score of ESA. Moreover, the predictor variables can be listed respectively as follows depending on their significance: meaning in life, search for meaning in life, and SPRR role satisfaction.
\end{abstract} görülmüştür. Ayrıca ERKA rol dengelemesinin anlamlı bir yordayıcı olmadığı, yordayıcı olan diğer değişkenlerin göreli önem düzeyinin sırasıyla YAÖ yaşamda anlamın varlığı, YAÖ yaşamda anlamın aranması ve ERKA rol doyumu olduğu bulgularına ulaşılmıştır.
Keywords: Parent, Meaning In Life, Parental Perception, Psychological Endurance

\section{Anahtar sözcükler: özel gereksinimli çocuk ebeveyni, yaşamda} anlam, ebeveynlik algısl, psikolojik dayanıklılık

\section{Introduction}

\section{EXTENDED ABSTRACT}

Every individual tries to enrich his/her life and to make it more meaningful. In the search for meaning, some individuals embrace nature, some of them get involved in art while others try to add meaning to life with what they can do in their daily lives. Parents can also create the meaning of their lives with the dreams they have built on their children as well as on what their children do and contribute to them. When parents have a child with special needs, their search for meaning in their lives may change. On the other hand, while adapting to the new life process, the disabilities of their children can cause psychological challenges for the parents, and this process may positively or negatively affect the psychological resilience of these parents.

Psychological endurance is described as a person's ability to fight against important sources of stress and recover from stress (Masten, 2001; Tusaie and Dyer, 2004). It is also a term referring to adapting to the new life by accepting it with its challenges using the ability to quickly recover from illness, depression, sudden changes, or bad situations (Wagnild and Young 1993; Alvord and Grados 2005; Earvolino-Ramirez, 2007). It is pointed out in the literature that psychological resistance to distress, anxiety and depression caused by the difficulties of being a parent has a protective and positive effect on the functioning of the family (Bekhet, Johnson, Zauszniewski, 2012; Migerode, Maes, Buysse and Brondeel, 2012; Bitsika, Sharpley and Bell; McConnell and Savage, 2015).

\footnotetext{
${ }^{1}$ Doç. Dr., Marmara Üniversitesi, Atatürk Eğitim Fakültesi, Özel Eğitim Bölümü, email: aydanaydin@marmara.edu.tr ORCID: 0000-0001-5936-1052
} 
Research also indicates that parents of children with special needs have higher levels of anxiety, stress and depression and lower levels of self-esteem and life satisfaction when compared to other parents (Akkök, 1989; Toros, 2002; Özşenol, Ünay, Aydın, Akın and Gökçay, 2002; Macias, Saylor, Rowe and Bell, 2003; Duarte, Bordin, Yazigi and Mooney, 2005; Dereli and Okur, 2008; Harper, Dyches, Harper, Olsen Roper and South, 2013; Bitsika, Sharpley and Bell,2013; Lu and Yang, Skora, Wang, Cai, Sun and $\mathrm{Li}, 2015)$. As can be realized from the findings of these research studies, on the one hand, the difficulties that the special needs child brings to the family life often cause the parents to experience psychological difficulties. On the other hand, considering the characteristics of these parents showing resistance to difficulties, it can be stated that they do their best by finding the meaning in life and accepting the truth as it is while coping with hardships (Coutu, 2002).

Parents of children with special needs may have difficulty in overcoming the challenges arising from the disabilities of their children, and thus their search for meaning in life may be negatively influenced. Meaning in life is formed when the individuals have a purpose enabling them to make sense of their life, establish relationships with others and do things that will benefit other people (Adler, 1997; Reker and Woo, 2011). It is also stated that meaning in life has an influence on human well-being and negative emotions decrease as a result of this influence (Feldman and Synder, 2005; Hicks and King, 2007; Steger, Oishi and Kashdan, 2009; Şahin, Aydın, Sarı, Kaya and Pala, 2012; Steger and Kashdan, 2013; Grouden and Jose, 2015). It can be argued that the search for meaning in life by parents with children having special needs may affect these parents' psychological endurance because of the characteristics of their children. Additionally, the mental and emotional difficulties experienced by parents have the potential to influence their questioning of their own parenting and how they feel as mothers and fathers. In other words, the experience of such parents with their children and their self-perceptions about their parenting roles may have an impact on their psychological resilience.

Functions determining the self-perceptions of parenting can be listed as follows: competence, role satisfaction, investment and role balancing (MacPhee et al., 1986; as cited in Güler and Yetim, 2008). Selfperception of parental role represents how parents perceive themselves as mothers and fathers. Perceived parental competence is related to the parents' ability to perform tasks related to the children (DeMontigny and Lacharite, 2004). In case of special conditions, such as autism, behavior problems and similar other problems of their children, parental competence perception is negatively influenced (Hastings and Brown, 2002; Jones and Ritz, 2005). When people become "parents", they take on the roles of "father" and "mother". Although this may look like a positive experience for many parents, it is difficult to adjust to the financial burden, psychological pressure of child rearing, and interpersonal relationships (Hyun, 2000).

Another noteworthy term within the scope of this study is parental investment referring to the use of available opportunities, the effort parents make and how much time they spend with their children (Corwyn and Bradle, 1999; Ma, Lai \& Pun, 2002; Rosemary, Hopcroft \& Martin, 2014). Parents of children with special needs have higher levels of investment (Ma, Lai and Pun, 2002) because they invest in material resources to treat their children's disability (McConnell and Savage, 2015). On the other hand, role balancing is a term referring to the parental balance of various roles (Perry-Jenkins, Repetti and Crouter, 2000). The psychological resilience of parents who have children with special needs may be influenced by their efforts to respond to the needs of the whole family, to regulate their investments in their children and to plan their roles in the family.

Therefore, the aim of this study is to investigate the relationship of meaning in life and selfperceptions about parental roles to the psychological resilience of parents with special needs children. In line with the aim of this study, the following research questions were formulated:

1. Is the meaning in life (i.e., existence of meaning in life and search for meaning in life) and the self-perceptions of the parental role (i.e., competence, role satisfaction, investment and role balancing) related to the psychological resilience of parents with special needs children?

2. Do the self-perceptions of parents with special needs children about the meaning in life and their parental role predict their psychological resilience?

\section{Method}

Hierarchical regression analysis was applied to reveal the relationship between the dependent and independent variables of the present study. 406 special needs children who are attending rehabilitation centers in Istanbul took part in this study. Of these children with special needs, $186(45.9 \%)$ were mentally handicapped, 142 (35\%) were autistic, and 54 (13\%) were children diagnosed with cerebral palsy. The data collection instruments utilized in this study are as follows: the Meaning in Life Questionnaire (MLQ), Self-Perception of Parental Role (SPRR) and Endurance Scale for Adults (ESA). 


\section{Findings and Discussions}

This study delved into the relationship of meaning in life and self-perceptions about parental roles of parents with special needs children to their psychological resilience. It was revealed that the there is a significant relationship between the total score of the ESA and the MLQ sub-dimension of "search for meaning in life", the MLQ sub-dimension of "existence of meaning in life", the SPRR sub-dimension of "role satisfaction" and the SPRR sub-dimension of "role balance". As a result of multiple linear regression analysis, it was uncovered that the relationship of the MLQ sub-dimension of "search for meaning in life", the MLQ sub-dimension of "the existence of meaning in life", the SPRR sub-dimension of "role satisfaction" and the SPRR sub-dimension of "role balance" to the total score of the ESA is significant.

These variables explain $18 \%$ of the total variance of the total score of ESA. Therefore, it is realized that the SPRR sub-dimension of "role balancing" is not a significant predictor, and the relative significance level of the other predictive variables is respectively as follows: "existence of meaning in life", "search for meaning in life" and "role satisfaction" sub-dimension of SPRR.

These findings demonstrate that finding meaning in life has a positive effect on the psychological resilience of parents with special needs children. Moreover, it would be true to conclude that these parents' satisfaction with their parental roles and role balancing within the family have a positive influence on their psychological resilience.

\section{GíRiş}

Dünyaya gelen her birey var olduğu müddetçe yaşamını güzelleştirmeye ve anlam katmaya çalışır. Bu anlam arama çabası bireyin tüm yaşamında çeşitli şekillerde kendini gösterebilir. Kimi bu arayışta doğaya kucak açar, kimi sanata kimi de günlük yaşamada yapabildikleri ile yaşamına anlam katmaya çalışır. Ebeveynler de çocuk sahibi olmaları ile birlikte çocukları üzerine kurdukları hayaller, çocuklarının yaptıkları ve kendilerine kattıkları ile yaşamlarındaki anlamı zenginleştirebilirler. Ebeveynler, özel gereksinimli bir çocuğa sahip olduklarında ise yaşamlarındaki anlam arayışları ve anlamı bulmaları değişikliğe uğrayabilir. Diğer yandan yeni yaşam sürecine uyum sağlarken engelin getirdiği güçlükler nedeniyle psikolojik olarak zorlanabilir ve bu süreç ebeveynlerin psikolojik dayanıklılıklarını olumlu veya olumsuz etkileyebilir. Ayrıca ebeveynler özel gereksinimli çocukları ile yaşarken kendi ebeveynliklerini sorgulayabilirler. Özellikle kendilerini ebeveyn rollerinde nasıl gördükleri ve nasıl hissettikleri de ebeveynlerin psikolojik dayanıklılıkları ile ilişkili olabilir. Özel gereksinimli bireylerin ebeveynlerinin gerek yaşamda anlam bulmaları gerekse de ebeveyn rolüne ilişkin kendilik algılarının psikolojik dayanıklılıklarının üzerinde etkili olacağı düşünülebilir.

Özel gereksinimli bir çocuğun aileye katılımı, aile üyelerinin yaşamlarını, duygularını, düşüncelerini ve davranışlarını olumsuz yönde etkileyerek; şok, karmaşıklık, yas, hayal kırıklığı, inkâr ve suçluluk gibi birçok duygu yaşamalarına neden olabilir (Akkök, 2003; Küçüker, 1993). Bu durum mevcut sistemi köklü değişikliklere uğratmakta ve gerilim yaratmaktadır (Doğan, 2015). Araştırmalar, özel gereksinimli çocuk ebeveynlerinin, diğer ebeveynlere kıyasla kaygı, stres ve depresyon düzeylerinin yüksek olduğunu buna karşılık özsaygıları ve yaşam doyumlarının düşük olduğunu (Akkök, 1989; Toros, 2002; Özşenol, Ünay, Aydın, Akın ve Gökçay, 2002; Macias, Saylor, Rowe ve Bell, 2003; Duarte, Bordin, Yazigi ve Mooney, 2005; Dereli ve Okur, 2008; Harper, Dyches, Harper, Olsen Roper ve South, 2013; Bitsika, Sharpley ve Bell,2013; Lu ve Yang, Skora, Wang, Cai, Sun ve Li, 2015) göstermektedir. Özellikle de çocuğun bakımını üstlenen annelerin normal gelişim gösteren çocukların annelerine kıyasla daha fazla stres yaşadıkları (Hayden ve Goldman, 1996; Rodriguez ve Murphy, 1997; Uğuz, Toros, İnanç ve Çolakkadığlu 2004; Dereli ve Okur 2008), buna bağlı olarak da dışlanma, hayal kırıklığı ve suçluluk hissettikleri bildirilmiştir (Kuhlthau, Payakachat, Delahaye, Hurson, Payne, Kovacs ve Tilford, 2014). Araştırma sonuçlarından da görüleceği gibi, özel gereksinimli çocuğun ailenin yaşamına getirdiği güçlükler sıklıkla ebeveynlerin psikolojik olarak zorlanmalarına neden olmaktadır.

Çocuğun en temel fizyolojik ihtiyaçlarını karşılayan, çevreden gelen maddi ve manevi her türlü zararlı etkilerden onu koruyan, ona yaşanabilir bir çevre oluşturan ailedir (Kır, 2011). Özel gereksinimli çocukların ailelerinde de sözü edilen bu temel ihtiyaçları karşılamak için ebeveynler büyük çaba göstermektedirler. $\mathrm{Bu}$ süreçte ebeveynlerin yaşanan ve yaşanması olası güçlüklerle baş edebilmeleri için psikolojik dayanıklılıklarının önemli olduğu düşünülmektedir. 
Zorluklar karşısında dayanıklılık gösteren bireylerin özelliklerine bakıldığında; yaşamda anlam bulmak ve zor zamanlar geçirirken gerçeği olduğu gibi kabul ederek ellerinden geleni yaptıklarından söz edilmektedir (Coutu, 2002). Özel gereksinimli çocuk ebeveynlerinin, hem çocuklarının engelini kabullenmeleri hem de engelin getirdiği güçlüklerle baş etmede güçlük yaşadıkları bilinmektedir. Tüm bu güçlüklerin yanında aile bireylerinin tüm ihtiyaçlarına karşılık vermek ve ebeveynlik rollerini yerine getirmekte zorlanmaları sonucunda güçlüklerle baş etmek için kendilerine yeni bir bakış açısı geliştirebilirler. Ebeveynlerin uyum sağlama sürecinde yaşamları ve beklentileri de farklılaşabilir, yaşam amaçlarını gözden geçirmek durumunda kalabilirler. Başka bir deyişle özel gereksinimli çocuklarının varlığı yaşamda anlam aramaları ile anlamın varlığına ilişkin yaklaşımlarını etkileyebilir. Bu durum ebeveynlerin psikolojik dayanıklılıkları ile ilişkili olabilir.

Yaşamda anlam; bireyin yaşamını anlamlandırmasını sağlayan bir amacının olması, başkalarıyla kurulan ilişkiler, maneviyat ve başka insanların da yararına olacak işler yaparak oluşur (Adler, 1997; Reker ve Woo, 2011). İnsan var olduğundan bu yana kendisinin ve dünyanın varoluşuna bir anlam katmaya çalışmıştır (Sezer, 2012). İnsanın çabalarını yönelteceği ideallere ihtiyacı vardır; anlam, amaç ve değer olmadan yaşamanın önemli ölçüde stres yarattığı ifade edilmektedir (Yalom, 2001). Yaşamda anlamın, insanın iyi hissetmesi üzerinde etkisi olduğu ve olumsuz duyguların azaldığı (Feldman ve Synder, 2005; Hicks ve King, 2007; Steger, Oishi ve Kashdan, 2009; Şahin, Aydın, Sarı, Kaya ve Pala, 2012; Steger ve Kashdan, 2013; Grouden ve Jose, 2015) bildirilmiştir. Bireyin yaşamda kendi anlamını bulması bir eser yaratmak, bir iş yapmak, bir insanı sevmek ve kaçınılmaz olan acı karşısında acıya neden olanı değil, acıya olan tavrını değiştirmek ile mümkündür (Frankl, 2012). Aynı zamanda acı veren deneyimlerden de yeni anlamlar çıkarmaları kişilerin yaşamda anlam bulmalarına yardım edebilir. Başka bir deyişle; bireylerin yaşamdan beklentileri, amaçları ve ulaşılan hedefleri ile kendilerini gerçekleştirmeleri yanında yaşanan olumsuzluklar karşısında kabullenici olarak yeni amaçlar edinmeleri yaşamda anlam bulmalarını sağlayabilir. Özel gereksinimli bireylerin ebeveynlerinin beklentileri ve hedeflerine ulaşmaları çoğunlukla çok kolay olmayacaktır. Buna göre bazı durumlarda hedeflerini yeniden gözden geçirmek durumunda kalabilirler. Bu durumda yaşadıkları farklı durumlara ve zorluklara uyum sağlamaları ve yeni koşullar altında yaşamda başka anlamlar bulmalarının ebeveynlerin psikolojik dayanıklılıklarını etkileyebileceği düşünülebilir.

Ebeveynlerin yaşadığı zihinsel ve duygusal zorlanmalar onların kendi ebeveynliklerini sorgulamaları ve ebeveyn olarak nasıl hissettikleri ile ilişkili olabilir. Başka deyişle, ebeveynlerin çocuklarıyla ilgili yaşadığı deneyimlerin, ebeveynlik rollerine ilişkin kendilik algılarının ebeveynlerin psikolojik dayanıklılığını etkileyebileceği düşünülebilir.

Ebeveynin kendilik değerlendirmeleri, ebeveynin benlik duygusunu etkilemekte ve çocuk yetiştirme stillerini şekillendirmektedir (Bornstein, Hendricks, Hahn, Haynes, Painter ve Tamis- LeMonda, 2003). Ebeveynliğe ilişkin kendilik algısını belirleyen işlevler; yeterlik, rol doyumu, yatırım ve rol dengeleme olarak tanımlamıştır (MacPhee ve diğ., 1986; Akt. Güler ve Yetim, 2008). Ebeveyn rolüne ilişkin kendilik algısı, ebeveynin anne ve baba olarak kendini nasıl gördüğü ve ebeveynlik rolüne ilişkin inancını temsil eder. Özel gereksinimli bir çocuğun aileye katılımı ile ebeveynler birçok güçlüğün üstesinden gelmeye çalışırken aynı zamanda çocuklarının bakımı ve eğitimi ile de ilgilenmek durumunda kalırlar. Çocuklarının geleceği ile ilgili doğru kararları verebilmek, uygun hizmetleri alabilmek arayışı içerisinde sürekli çaba gösterirler. Ebeveynlerin hem ailelerinin hem de çocuklarının ihtiyaçlarına karşılık verebilmeleri için fiziksel ve zihinsel olarak sürekli bir faaliyet halinde olmaları gerekmektedir. Bu çaba ve koşturma halinde ebeveynler her şeye yetişebilmek isterken kendilerini yetersiz hissedebilirler ya da bu zorlu uğraşları vermeleri kendilerini daha da güçlü hissetmelerine neden olabilir.

Yeterlik inancı bireylerin zorluklar ve sıkıntılı durumlar karşısında sabırlı olmaları ve kendilerini motive edebilmeleri üzerinde etkilidir. Yeterlik inancı düşük olan bireyler güçlükler karşısında çabalamaktan kolayca vazgeçerken, yeterlik inancı yüksek bireyler azimle çabalar ve dayanıklılıklarını korurlar (Bandura, 2006). Algılanan ebeveyn yeterliliği; ebeveynin çocuğu ile ilgili görevleri yerine getirebilmesi ile ilişkilidir ve ebeveynin yeteneklerini kullanabilmesi konusunda karar verebilmesi ya da buna inanması şeklinde tanımlanabilir (DeMontigny ve Lacharite,2004). Annelik rolüne ait özelliklerden bir olan yeterliğin annelerin bebekleriyle ilişkilerinde önemli rolü vardır. Öz-yeterliliği yüksek olan annelerin bebekleriyle ilişki kurabilme, onları sakinleştirebilme, tepkilerini kontrol edebilme gibi annelik davranışlarını gerçekleştirebildikleri bildirilmiştir. Buna ek olarak, çocuklarının da daha olumlu davranışlar sergilediği, 
öz-yeterliği kısmen düşük annelerin ise annelik davranışlarında daha az duyarlık görüldüğü ve çocuklarının uygun olmayan davranışlar gösterdikleri bildirilmiştir (Leerkes and Crockenberg, 2002; Jones and Ritz, 2005; Weaver, Shaw, Dishion ve Wilson, 2008). Diğer yandan, ebeveynin yeterliği ile çocukların bilişsel gelişimi arasında olumlu yönde bir ilişki olduğu ancak uygun olmayan davranışları ile negatif yönlü bir ilişki olduğu gözlemlenmiştir (Coleman and Karrake, 2003). Ayrıca bebeklerin mizaçları ve zor bebek olmaları ebeveynlerin kendilerine yönelik inançlarını etkilerken, çocukların problem davranışları ebeveynlerin duygusal zorlanmalarına neden olarak, yeterliklerini etkiler (DeMontigny ve Lacharite,2004; Rezendes ve Scarpa, 2011). Çocukların otizm, davranış problemleri vb. özel bir durumu olduğunda da ebeveyn yeterlik algis1 olumsuz etkilenmektedir (Hastings ve Brown, 2002; Jones and Ritz, 2005). Ebeveynin çocuk yetiştirmekle ilgili yaptıkları ile ebeveynlik yeterlik algıları arasında güçlü bir ilişki vardır ve aldıkları sosyal destekler de bunlarla ilişkilidir (MacPhee, Fritz ve Miller-Hely, 1996; Holloway, Suzuki, Yamamoto ve Behrens, 2005). Sosyal destek aynı zamanda annenin yaptı̆̆ 1 iyi şeyler konusunda geri bildirim almasına, kendini geliştirmesine ve başarısız olduğu zamanlarda da bunun çocuğunun özelliklerine atfedilmesi yoluyla, annenin kendini yeterli hissetmesine yarar (Leerkes and Crockenberg, 2002). Ayrıca kendini yetkin hisseden ebeveynlerin kendilerini daha çok yeterli hissetmesi ve ebeveynlik rolünden memnun olması ilişkilidir (MacPhee, Fritz ve Miller-Hely, 1996). Roller fonksiyonu, ailenin maddi ve manevi ihtiyaçlarını karşılayan davranış kalıplarıdır ve ailenin kaynaklarının kullanımı, çocuğunu bakıp büyütme, destekleme, kişisel gelişimi sağlama ve aile sistemini idare etme gibi konularla (Bulut,1993) ilişkilendirilmektedir. Bir kişi "ebeveyn" olduğunda "baba" ve "anne" olarak yeni sosyal statüsünü kazanarak yeni ebeveyn rollerini yürütmeye başlarlar. Bu yeni süreç çoğu ebeveyn için olumlu ve tatmin edici bir deneyim olabilirken mali yük, çocuk yetiştirmenin psikolojik baskısı ve yeni kişilerarası ilişkilerin geçişini ayarlamak zor bir olaydır; bu faktörler yaşam doyumunun düşmesine neden olabilir (Hyun, 2000). Çocuğun bakımından genellikle anneler sorumlu olduğundan, annelik rolü başta çocuğun sağlık, bakım ve yetiştirilmesi sürecinde yer alan pek çok görev ile ilişkilidir. Ancak değişen toplum ve ekonomik nedenler ile babalık rolü de değişime uğramıştır. Araştırmalardan da görülebileceği gibi; geçmişteki toplumsal ve kültürel beklentiler babanın sadece çalışmasına ve evi geçindirmesine yönelik iken, günümüzde babalar da çocuklarının bakımı ve eğitiminde sorumluluk almaya (Seabra, 2007; Kuzucu, 2011) başlamışlardır. Ancak babaların iş ve aile yaşamlarında çekişmeler söz konusu olduğunda; babalık rollerini daha az kabul ettikleri görülmüştür. (Corwyn ve Bradle, 1999). Zihin engelli çocuğu olan ebeveynlerin, bu rol ve sorumluluklarının yanında çocuklarının ek özel ihtiyaçları ile de ilgilenmeleri gerekmektedir (Schieve, Blumberg, Rice, Visser ve Boyle, 2007). Otistik çocuk annelerinin de tüm zamanlarını otistik çocuklarına ayırmak konusunda kendilerini baskı altında hissettikleri ve diğer çocuklarını ihmal etmekten dolayı da suçluluk hissettikleri belirtilmiştir (Kuhlthau ve di ̌̆., 2014). Diğer yandan özel gereksinimli çocukların ebeveynleri çocuklarının bakımı, sağlık kontrolleri, eğitim hizmetlerinin sağlanması ve normal gelişim gösteren çocukların ebeveynlerine kıyasla daha çok eğitimci rolünü de üstlenmek durumunda kalırlar. Tüm bu rollerin hepsini üstlenirken çoğunlukla emeklerine karşlık almak için daha çok zaman ve emek harcamak zorundadırlar. $\mathrm{Bu}$ durum ebeveynlerin anne ve baba olarak rollerinden doyum almalarını almalarını farklı şekillerde etkileyebilir.

Özel gereksinimli çocuk ebeveynlerinin çocuğun geleceği hakkında korku ve engellenme yaşayabileceği, diğer çocuklar gibi öğrenip öğrenemeyeceklerini ve bağımsız bir yetişkin olarak yaşayıp yaşamayacaklarını merak ettikleri bildirilmiştir (Duman, 1995; Özşenol ve diğ.) Ebeveynlerin yaşadıkları bu korkular ebeveynlerin kendilerini çoğunlukla endişeli ve gergin hissetmelerine neden olabilir. Bu olumsuz duyguların ve aile bireylerinin ihtiyaçlarına yetişebilmek için gösterdikleri çabaların, ebeveynlerin rollerinden daha az doyum almalarına neden olacağı düşünülebilir. Ebeveynlerin çocuklarına yaptıkları yatırımlar da ebeveynlik algılarını etkilemektedir. Henüz çocuk doğmadan evvel çocuk üzerine kurulan hayaller ile başlayan yatırım süreci, ailenin çocuğu için sunduğu maddi ve manevi tüm kaynakları kapsar. Çocuğun doğumundan önce çocuk üzerine kurulan hayaller ve beklentileri ebeveynlerin çocuğuna ilişkin ilk duygusal yatırımlarını oluşturur. Özel gereksinimli çocuğun aileye katılımı ile ebeveynlerin ilk duygusal yatırımları hayal kırıklığı ile olumsuz etkilenir. İlerleyen yaşlarda ise ebeveynlerin maddi ve manevi yatırımları yeniden şekillenmek durumunda kalır. Ebeveynlerin çocukları için yaptığı harcamalar, çocukları ile geçirdiği zaman, çocuklarının bakımı ve eğitimi için seçimlerin tamamı ebeveynlerin çocuklarına yaptıkları yatırımlardır.

Ebeveynlerin çocuklarına ilişkin yatırımları farklı şekillerde ifade edilmektedir. Doğrudan yatırım çocuğun beslenmesi, kucaklamak, temizlemek vb. ile ilgili iken dolaylı yatırım çocuğu gelecek garantisi olarak görmek ve neslin devamı olarak (Quilan, 2007)görmektir. Diğer yandan mali yatırım: çocuk yetiştirirken 
yapılan harcamalar ve mali planlamalar; duygusal yatırım: duygusal bağl1lık, temel bakıma yatırım: temel bakım ile ilgili; Entelektüel yatırım: zihinsel gelişimi hakkındaki kaygılar (okul seçmek, kurslar vb.), sosyal-ruhsal yatırım: toplumsal yaşam, ahlaki değerler ve dini inançla ilgili ve son olarak da ailevi-kişisel yatırım: ebeveynlerin sağlıklı olmasının, ailedeki bireylerin önemiyle ilgili yatırımlar şeklinde de sınıflandırılabilmektedir. Anne ve babaların çocuklarına en çok duygusal yatırım yaptıkları, annelerin temel bakım ile ilgili yatırımlarının, babaların ise entelektüel yatırımlarının daha çok olduğu bildirilmiştir (Bandeira ve Seidl-de-Moura, 2012). Ayrıca ebeveyn yatırımı anne-babanın çocuğunu büyütürken elindeki imkânları kullanışı, gösterdiği çaba ve çocuğu ile ne kadar zaman geçirdiğini kapsar (Corwyn ve Bradle, 1999; Ma, Lai ve Pun, 2002; Rosemary, Hopcroft ve Martin,2014). Ebeveynlerin yatırımları gelir durumları ile de ilişkilidir. Eğer ebeveynlerin gelir durumları yüksek ise, çocuklarına daha iyi bir çevre sunma ve gelişimlerini destekleyici materyaller sunma firsatları olacağından kendilerini de daha iyi hissedeceklerdir. Başka deyişle gelir durumları ebeveynlerin davranışları ile dolaylı olarak ilişkilendirilebilir ve ebeveynlik davranışlarını etkileyebilir (Yeung, Linver and Brooks-Gunn, 2002). Ancak maddi olmayan ebeveyn yatırımları daha çok ebeveynlerin duygusal süreçleri ile ilgilidir. Anneler çocuğun bakımından ve eğitiminden kendilerini daha çok sorumlu hissetmekte ve buna yönelik daha çok çaba harcamaktadırlar. Ancak babalar, gönülsüzce çocuğun bakımı rolünü üstlenmek zorunda kalırlarsa, çocuk için yatırımlarının azaldığı ve iş hayatı gergin olduğunda, çocuklarına yönelik sosyo-duygusal yatırımları olumsuz etkilenmektedir. (Corwyn ve Bradle, 1999). Diğer yandan ebeveyn yatırımı çocukların problemleriyle yüzleşirken ebeveynlerin gösterdikleri dayanıklılığını da içerir. Olumsuz duygulara rağmen resmi tanılı çocukların ebeveynlerinin yatırım seviyeleri yüksek çıkmıştır (Ma, Lai ve Pun, 2002), çünkü aileler çocuklarının yetersizliklerine yönelik tedaviler için dikkate değer biçimde enerji ve maddi kaynaklarını kullanarak yatırım yapmaktadırlar (McConnell ve Savage, 2015). Diğer yandan özel gereksinimli çocuk ebeveynleri çocuklarının bakım, rehabilitasyon, eğitim ve sosyalleşmeleri için sürekli yatırımlarını düzenlemek durumundadırlar. Tüm bu süreçte hem maddi yatırımlarını sürekli gözden geçirmek ve ailenin diğer bireylerinin ihtiyaçları için düzenlemeler yapmak zorundadırlar. Çocuklarının bakımı, eğitimi, gerekli hizmetleri alması için ulaşımı sağlamak ve geçirilecek zamanı planlamak gibi yatırımlarını düzenlemek için aile içindeki rolleri dengelemek durumunda kalırlar.

Ebeveynlik; ebeveynin kişilik özellikleri, çocuğun kişilik özellikleri, toplumsal bağlamda ebeveyn-çocuk ilişkisi, sosyal ilişkiler ve ebeveynin iş hayatı ile etkileşim içerisindedir (Belsky, 1984). Annelerin ebeveynlik algısı, ebeveynlerin rollerine ilişkin yeterlikleri, rollerinden tatmin olmaları, çocuk yetiştirme ile ilgili yatırımları ile hem ebeveynlik hem de diğer sosyal rollerini dengelemeleri ile ilişkilendirilebilir (Bornstein ve Cote, 2004). Rol dengeleme; ebeveyn, eş ve çalışan olarak kişinin elinde bulundurduğu rolleri etkili bir biçimde dengede tutmasıdır (Perry-Jenkins, Repetti ve Crouter, 2000). Her aile kendi sistemi içinde rol dengelemesini kendi koşullarına göre uyarlamaya çalışırken, özel gereksinimli çocuğun varlığ rol dengelemesinde değişikliklere yol açabilir. Başka deyişle, özel gereksinimli bir çocuğun varlığ ve ihtiyaçları aile içindeki rollerin yeniden düzenlenmesini gerektirir. Çünkü ailenin çocuğun yetiştirilmesi ile ilgili bazı kararları vermesi ve bazı sorumlulukları paylaşması gerekmektedir. Bu süreçte, aileler rol ve işlevlerde karışıklık yaşayabilirler. Aile üyelerinin sorumluluğu, üyelerin iletişim ilişkileri, statüleri ve bu statülerden beklenen rollere göre (Özşenol ve diğ., 2003) değişmektedir. Yapılan bir çalışmada OSB'li çocuk ebeveynlerinin hem bakım veren hem de öğretmen rolünü üstlendikleri bildirilmiştir (Hoogsteen ve Woodgate, 2013). Diğer yandan özel gereksinimli çocuk ebeveynlerinin rolleri dengelemek için sadece bir kez düzenleme yapmaları yeterli olmayabilir. Değişen koşullar ve ihtiyaçlara göre çeşitli defalarca yeni düzenlemeler yapmak gerekebilir. Ebeveynlerin tüm ailenin ihtiyaçlarına karşıllk verebilmek, çocuklarına ilişkin yatırımlarını düzenlemek ve aile içindeki rollerini planlamak için gösterdikleri çabalar onların psikolojik dayanıklı olmalarını etkileyebilecektir.

Psikolojik dayanıklılık; hastalıktan, depresyondan, değişimlerden ya da kötü durumlardan çabucak iyileşme yeteneği ile değişimin üstesinden gelerek uyum sağlama ve zor durumlara karşı yaşamı kabul ederek dengede olma durumudur (Wagnild ve Young 1993; Alvord and Grados 2005; Earvolino-Ramirez, 2007). Genel anlamıyla uyum sağlama sürecini ifade eden psikolojik dayanıklılık; önemli stres kaynakları karsısında (travma, tehdit, trajedi, ailevi sıkıntılar, sağlık problemleri, işyeri, parasal sorunlar vb) kişinin mücadele etme ve kendini toparlama gücü olarak ifade edilmektedir (Masten, 2001; Tusaie ve Dyer, 2004). Aynı zamanda stresli yaşam olayları ile karşılaşıldığında bir direnç kaynağı olarak çalışan kişilik özelliğidir (Terzi, 2008). Psikolojik olarak dayanıklı bireylerin stresli yaşam olayıyla, daha başarılı bir biçimde mücadele ettikleri, etkili problem çözme yeteneği ve etkili kişiler arası iletişim becerileri gibi olumlu özelliklere sahip oldukları saptanmıştır (Öz ve Bahadır Yılmaz, 2009). 
Özel gereksinimli çocuk ebeveynlerinin karşılaştıkları güçlüklerle baş edebilmelerinde psikolojik dayanıklıklarının önemli bir etkisi olduğu söylenebilir. Yapılan araştırmalarda; ebeveyn olmanın getirdiği güçlükler nedeniyle yaşanan sıkıntı, kaygı ve depresyona karşı psikolojik dayanıklılığın koruyucu etkisi olduğu ve ailenin işlevlerini yerine getirmede olumlu etkisi olduğu (Bekhet, Johnson, Zauszniewski, 2012; Migerode, Maes, Buysse ve Brondeel, 2012; Bitsika, Sharpley ve Bell, 2013; McConnell ve Savage, 2015) bildirilmiştir.

Diğer yandan özel gereksinimli çocuk ebeveynlerinin kendi ebeveynlik rollerinde kendilerini yeterli hissetmelerinin, yatırımları ile rollerini düzenlemelerinin ve yaşamda anlam bulmalarının psikolojik dayanıklılıklarını etkileyebileceği düşünülmektedir. Başka bir deyişle; ebeveynlik rollerini ve yatırımlarını dengeleyebilen, çocuklarıyla etkileşimlerinde kendini yeterli hisseden ebeveynlerin yaşamda anlam bulmaları ve özel gereksinimli çocuklarının sorunlarıyla mücadele ederken psikolojik olarak daha dayanıklı olabilecekleri söylenebilir. Bu varsayımdan hareketle özel gereksinimli çocuk ebeveynlerinin yaşamda anlam ve kendilik algılarının psikolojik dayanıklıklarıyla ilișkisinin incelenmesinin önemli olduğu düşünülmüştür. $\mathrm{Bu}$ araştırmada da özel gereksinimli çocuk ebeveynlerinin yaşamda anlamın varlığı ve yaşamda anlamın aranması ile ebeveyn rolüne ilişkin kendilik algılarının psikolojik dayanıklılıkları ile iliş̧isinin incelenmesi amaçlanmıştır. Bu araştırmanın amacı; özel gereksinimli çocuk ebeveynlerinin yaşamda anlam ve ebeveyn rolüne ilişkin kendilik algılarının psikolojik dayanıklılıkları ile ilişkisini incelemektir. Bu kapsamda bu çalışmanın araştırma soruları;

1. Özel gereksinimli çocuk ebeveynlerinin yaşamda anlam (yaşamda anlamın varlı̆̆ı ve yaşamda anlam aranması) ve ebeveyn rolüne ilişkin kendilik algıları (yeterlilik, rol doyumu, yatırım ve rol dengelemesi) ile psikolojik dayanıklılıkları arasında ilişki var mıdır?

2. Özel gereksinimli çocuk ebeveynlerinin yaşamda anlam ve ebeveyn rolüne ilişkin kendilik algıları, psikolojik dayanıklılıklarını yordamakta midır?

\section{YÖNTEM}

2.1 Araştırma Modeli: $\mathrm{Bu}$ araştırmanın modeli nicel araştırma desenlerinden ilişkisel tarama araştırmasıdır. (Büyüköztürk ve diğ., 2017). Araştırmanın bağımlı değişkeni ile bağımsız değişkenleri arasındaki ilişkiyi belirlemek için çoklu regresyon analizi yöntemlerinden özellikle eğitime yönelik çalışmalarda yoğun bir şekilde kullanılmaya başlayan (Noyan, Yıldız, 2006) hiyerarşik regresyon analizi kullanılmıştır.

2.2 Araştırmanın Örneklemi: Araştırma İstanbul'da rehabilitasyon merkezlerine devam eden özel gereksinimli çocuk ebeveynleri ile gerçekleştirilmiştir. Araştırmada kolayd ulaşılabilir örnekleme yöntemiyle seçilen 15 rehabilitasyon merkezinden, toplam 406 özel gereksinimli çocuk ebeveyni yer almaktadır. Özel gereksinimli çocukların ebeveynlerine uygulanacak ölçeklerin ulaştırılması, takibi ile ebeveynlere ölçme araçlarının bizzat uygulanabilmesi ve doldurulmasında yardıma ihtiyaçları olduğu düşünülerek, kolayda örnekleme yöntemi tercih edilmiştir. Örneklemin özelliklerine bakıldığında; 324 anne 82 babadan oluştuğu görülmektedir. Ayrıca ebeveynler ekonomik durumlarını çoğunlukla orta düzey (321 ebeveyn; \% 79'u) olarak bildirmişlerdir. Özel gereksinimli çocukların da 186' s1 (\%45,9) zihin engelli, 142 ' si (\%35) otizm ve 54 tanesi de (\%13) serebral paralizi tanısı olan çocuklardan oluşmaktadır.

\subsection{Veri Toplama Araçları}

2.3.1 Yaşamda Anlam Ölçeği: Orijinal adı "Meaning in Life Questionnaire (MLQ)" olan ve Steger ve arkadaşları tarafından 2006'da geliştirilen ölçek Demirbaş (2010) tarafından Türkçe'ye uyarlanmıştır. Ölçeğin 5'er maddeden oluşan iki alt ölçeği bulunmaktadır. Birinci alt ölçek "yaşamda anlamın varlığı", ikinci alt ölçek "yaşamda anlam aranması " olarak belirlenmiştir. Ölçek Likert tipi olup kategorileri "kesinlikle doğru değil 'den“"kesinlikle doğru'ya doğru sıralanmıştır. Ölçek maddelerinin 5'i olumlu 5'i olumsuz ifade şeklindedir. Ölçeğin uyarlanmasına ilişkin güvenirlik analizlerinde iç tutarlık katsayısı. 86 olarak bulunmuştur. Test tekrar test güvenirliği için yapılan iki uygulama sonucu arasındaki ilişki ise. 81 olarak hesaplanmıştır. Ölçeğin geçerlik çalışması için yapılan temel bileşenler analizinde ve doğrulayıcı faktör analizinde ölçeğin madde faktör yüklerinin yeterli, uyum iyiliğinin oldukça yüksek ve yap1 
geçerliliğini sağladığı görülmüştür. Ölçekte puanın yükselmesi bireyin yaşam anlam düzeyinin yüksek olduğu şeklinde yorumlanmaktadır.

2.3.2 Ebeveyn Rolüne İlişkin Kendilik Algısı Ölçeği (ERKA): Ölçek, MacPhee ve arkadaşları tarafından 1986 'da bireyin ebeveynlik rolünde kendisini ne derece yeterli gördüğü, rolünden aldığı doyum, rolüne yatırımı ve diğer yetişkin rolleri ile arasında ne derecede denge kurduğunu ölçmek amacıyla geliştirilmiştir. ERKA Ölçeğinin Uyarlaması Güler ve Yetim (2008) tarafından ikinci kuşak annelerden ve onların anneleri olup çalışmada anneanne adı ile anılacak birinci kuşak annelerden oluşan toplam 300 kişilik örneklem ile yapılmıştır. Yap1 geçerliğini sınamak amacıyla varimaks eksen döndürme yöntemi kullanılarak faktör analizi yapılmıştır. Analiz sonucunda, ERKA Ölçeği Türkçe uyarlamasından bazı maddeler atılarak orijinal dört faktörlü yapıya uyum sağlanmıştır ve dört bileşen toplam varyansın 49.91'ini açıklamaktadır. Bu Ölçeğin güvenirliğini sınamak için test-tekrar test ve ölçüt bağıntılı geçerliğini sınamak için de Yaşam Yönelimi Testi (YYT) kullanılmıştır. YYT ölçeğinin ERKA Ölçeği'nin yeterlilik alt ölçeği ile .64, rol doyumu ölçeği ile .30 ve rol dengelemesi alt ölçeği ile .29 düzeyinde ilişkili olduğu bulunmuştur. Ebeveyn Rolüne İlişkin Kendilik Algısı Ölçeği'nin alt ölçeklerinin güvenirliğini sınamak amacıyla hesaplanan Cronbach alfa iç tutarlık katsayılarına bakıldığında değerlerin .61 ile .68 arasında değiştiği görülmektedir. Benzer şekilde test-tekrar test güvenirlik katsayılarının .59 ile .70 arasında olduğu gözlenmiştir.

2.3.3 Yetişkinler İçin Psikolojik Dayanıklılık Ölçeği (PDÖ): Ölçek, Friborg ve arkadaşları tarafından 2003 'de geliştirilmiştir. Basım ve Çetin (2011) tarafından uyarlaması yapılan ölçeğin öncelikle Türkçe'ye çeviri ve geri çeviri çalışmaları yapılmış ve ölçek 350 öğrenci ve 262 çalışan örneklem gruplarına uygulanmıştır. Ardından Ölçeğin test-tekrar test güvenilirliği ile iç tutarlılığı araştırılmış, geçerliliği için ölçüt bağımlı geçerliliği ve doğrulayıcı faktör analizi yapılmıştır. Yapılan faktör analizi sonucunda, özgün ölçekle örtüşen ve 'Kendilik algısı, 'Gelecek algısı', 'Yapısal stil', 'Sosyal yeterlilik', 'Aile uyumu' ve 'Sosyal kaynaklar' boyutlarını içeren altı faktörlü yap1 doğrulanmıştır $(\chi 2=1104, \mathrm{df}=480, \chi 2 / \mathrm{df}=2,3$; RMSEA=0,055; TLI=0,90; CFI=0,91). Ölçüt bağımlı geçerliliği için Sosyal Karşılaştırma Ölçeği ve Kontrol Odağı Ölçeği kullanılmıştır. Ölçeğin alt boyutlarının iç tutarlılık katsayılarının 0,66 ile 0,81 arasında ve test-tekrar test güvenilirliklerinin ise 0,68 ile 0,81 arasında değiştiği bulunmuştur. Ölçekte toplam da 33 soru bulunmaktadır. Ölçekte puanın yükselmesi bireyin dayanıklılığın da yükseldiği şeklinde yorumlanmaktadir.

2.4 Verilerin Toplanması ve Analizi: Araştırma başlangıcında, İstanbul'da rehabilitasyon merkezlerinden 15'ine kurumlarla ilişkisi olan ve/veya çalışan özel eğitim öğretmenleri aracıllı̆̆ ile ulaşılmıştır. Ölçme araçlarını uygulayacak öğretmenlere öncelikle araştırmanın amacı, ölçeklerin kullanılış biçimi ve formları doldurulurken dikkat edilecekleri hususlar anlatılmıştır. Ardından kurumlarda ailelere ölçeme araçlarını ulaştıracak, takip edecek ve gerekli durumlarda (ebeveynin formu okuma-anlama ve nasıl dolduracağı konusunda yardıma ihtiyacı olduğu düşünüldüğünde), bizzat ebeveyne okuyarak, seçenekleri söylemek ve nereyi nasıl işaretleyeceği konusunda yardımcı olabilmesi için ölçme aracını uygulayacak özel eğitim öğretmenlerine açıklamalarda bulunulmuştur. Özel eğitim öğretmenlerinin kurumlarındaki öğrenci sayıları ve uygulama yapabilecekleri ebeveyn sayıları dikkate alınarak toplamda 600 form dağıtılmış, ancak tamamlanmamış ölçekler geçersiz sayılarak kalan 406 form araştırmaya dâhil edilmiştir. Araştırma verilerinin analizinde istatistiksel analiz yöntemleri kullanılmış ve veriler SPSS for Windows 15.0 programında analiz edilmiştir.

\section{BULGULAR}

Bu bölümde sırasıyla bağımlı (PDÖ ve alt boyutları) ve bağımsız değişkenlerin (YAÖ'nin alt boyutları ve ERKA'nın alt boyutları) betimleyici istatistikleri, bağımlı değişkenin bağımsız değişkenler ile ilişkisini inceleyen analizler ve ilişkili bulunan bağımsız değişkenlerin bağımlı değişkenleri yordamasına ilişkin regresyon analizleri yer almıştır. Bağımlı değişken olan PDÖ’nün hem toplam puanı hem de alt boyut puanlarının analizleri ayrı ayrı ele alınmıştır. 
Tablo1. Bağımlı ve Bağımsız Değisskenlerin Betimleyici İstatistikleri

\begin{tabular}{|c|c|c|c|c|c|c|c|c|c|c|c|c|c|}
\hline & $\begin{array}{l}\text { YAÖ } \\
\text { yaş. } \\
\text { an. } \\
\text { aran. }\end{array}$ & $\begin{array}{l}\text { YAÖ } \\
\text { yaş. } \\
\text { an. } \\
\text { var. }\end{array}$ & $\begin{array}{l}\text { PDÖ } \\
\text { yap1s } \\
\text { al } \\
\text { stil }\end{array}$ & $\begin{array}{c}\text { PDÖ } \\
\text { gelece } \\
\text { k alg1s1 }\end{array}$ & $\begin{array}{c}\text { PDÖ } \\
\text { aile } \\
\text { uyumu }\end{array}$ & $\begin{array}{c}\text { PDÖ } \\
\text { kendilik } \\
\text { alg1S1 }\end{array}$ & $\begin{array}{l}\text { PDÖ } \\
\text { sosyal } \\
\text { yet. }\end{array}$ & $\begin{array}{c}\text { PDÖ } \\
\text { sosyal } \\
\text { kaynak }\end{array}$ & $\begin{array}{l}\text { PDÖ } \\
\text { toplam }\end{array}$ & $\begin{array}{l}\text { ERKA } \\
\text { yeterli. }\end{array}$ & $\begin{array}{c}\text { ERKA } \\
\text { rol } \\
\text { doyumu }\end{array}$ & $\begin{array}{l}\text { ERKA } \\
\text { yatırım }\end{array}$ & $\begin{array}{c}\text { ERKA } \\
\text { rol } \\
\text { dengeleme }\end{array}$ \\
\hline $\mathrm{n}$ & 399 & 399 & 399 & 399 & 399 & 399 & 399 & 399 & 399 & 399 & 399 & 399 & 399 \\
\hline $\bar{X}$ & 20,62 & 23,88 & $\begin{array}{r}14,3 \\
4\end{array}$ & 13,65 & 21,96 & 22,45 & 21,57 & 25,77 & 119,74 & 17,72 & 12,59 & 11,13 & 11,50 \\
\hline S.s. & 8,48 & 5,84 & 3,49 & 4,20 & 5,75 & 5,28 & 5,33 & 6,15 & 22,99 & 4,45 & 3,23 & 3,36 & 3,95 \\
\hline $\begin{array}{l}\text { Çarpı } \\
\text { klık }\end{array}$ & ,09 &,- 86 &,- 10 &,- 24 &,- 29 &,- 36 &,- 26 &,- 27 &,- 17 & ,16 &,- 31 & ,08 & ,24 \\
\hline $\begin{array}{l}\text { Bas1 } \\
\text { klık }\end{array}$ &,- 88 & ,78 &,- 43 &,- 49 &,- 59 &,- 48 &,- 42 &,- 73 &,- 52 &,- 32 &,- 57 &,- 27 &,- 61 \\
\hline
\end{tabular}

Tablo 1'de bağımlı ve bağımsız değişkenlerin betimleyici istatistikleri verilmiştir. Yapılan analiz sonucunda çarpıklık ve basıklık değerleri referans alınarak tüm değişkenlerin normal dağılım koşullarını sağladığı sonucuna ulaşılmıştır.

Regresyon analiziyle bağımsız değişkenlerin yordayıcılığı test edilmeden önce bağımlı değişken olan PDÖ toplam puan ve alt boyutlarının sırasıyla bağımsız değişkenler ile anlamlı bir ilişki olup olmadığı test edilmiş daha sonra anlamlı ilişkisi olan bağımsız değişkenler regresyon analizine alınmıştır.

Tablo 2. PDÖ Toplam ve Alt Boyut Puanları ile Bağımsız Değişkenlerin Puanları Arasındaki İlişki

\begin{tabular}{|c|c|c|c|c|c|c|c|}
\hline & $\begin{array}{c}\text { PDÖ } \\
\text { yapisal } \\
\text { stil } \\
\end{array}$ & $\begin{array}{c}\text { PDÖ } \\
\text { gelecek } \\
\text { algis1 }\end{array}$ & $\begin{array}{c}\text { PDÖ } \\
\text { aile } \\
\text { uyumu }\end{array}$ & $\begin{array}{c}\text { PDÖ } \\
\text { kendilik } \\
\text { algis1 }\end{array}$ & $\begin{array}{c}\text { PDÖ } \\
\text { sosyal } \\
\text { yeterlilik } \\
\end{array}$ & $\begin{array}{c}\text { PDÖ } \\
\text { sosyal } \\
\text { kaynak } \\
\end{array}$ & $\begin{array}{l}\text { PDÖ } \\
\text { toplam }\end{array}$ \\
\hline YAÖ & & & & & & & \\
\hline $\begin{array}{l}\text { Yaşamda } \\
\text { anlamın } \\
\text { aranması } \\
\text { YAÖ }\end{array}$ & ,06 &, $19^{* *}$ &, $13^{*}$ & ,10 & ,08 &, $19 * *$ &, $17^{* *}$ \\
\hline $\begin{array}{l}\text { YAÖ } \\
\text { Yaşamda } \\
\text { anlamın } \\
\text { varlığ1 }\end{array}$ &, $17^{* *}$ &, $23^{* *}$ &, $28^{* *}$ &, $26^{* *}$ &, $29^{* *}$ &, $26^{* *}$ &, $33^{* *}$ \\
\hline $\begin{array}{l}\text { ERKA } \\
\text { yeterlilik }\end{array}$ & ,02 & ,05 & ,07 & ,10 & ,06 & ,04 & ,07 \\
\hline $\begin{array}{l}\text { ERKA } \\
\text { rol } \\
\text { doyumu }\end{array}$ &, $11^{*}$ & ,10 &, $20^{* *}$ &, $14^{* *}$ &, $17^{* *}$ &, $16^{* *}$ &, $20^{* *}$ \\
\hline $\begin{array}{l}\text { ERKA } \\
\text { yatırım }\end{array}$ & ,02 & ,02 & ,08 &,- 01 & ,02 & ,02 &, 03 \\
\hline $\begin{array}{l}\text { ERKA } \\
\text { rol } \\
\text { dengeleme }\end{array}$ & ,06 & ,09 &, $12^{*}$ &, $17^{* *}$ &, $10^{*}$ & ,08 &, $14^{* *}$ \\
\hline
\end{tabular}

PDÖ alt boyutlarından yapısal stil ile bağımsız değişkenlerin arasında anlamlı bir ilişki olup olmadığını belirlemek için yapılan Pearson korelasyon analizi sonucunda PDÖ yapısal stil puanının YAÖ yaşamda anlamın varlığ $(r=0,17 ; p<0,01)$ ve ERKA rol doyumu $(r=0,11 ; p<0,05)$ ile poz

itif yönde anlamlı bir ilişki bulunmuştur (Bakınız Tablo 2). PDÖ yapısal stil ile anlamlı ilişkisi bulunan bu değişkenler regresyon analizine alınmış ve sonuçları Tablo3'de sunulmuştur. 
Tablo 3. PDÖ Yapısal Stil Puanının Yordanmasına İliş̧kin Çoklu Regresyon Analizi Sonuçları

\begin{tabular}{cccccc}
\hline Değişken & B & Standart hata & Beta & T & p \\
\hline Sabit & 10,91 & 9,34 & & 11,65 &, 000 \\
YAÖ yaş. an. var & 0,09 &, 03 &, 16 & 3,11 &, 002 \\
ERKA rol doyumu &, 10 &, 05 &, 09 & 1,81 &, 07 \\
\hline
\end{tabular}

Çoklu doğrusal regresyon analizi sonucunda anlamlı bir model ortaya çıkmış $\left(\mathrm{R}=0,19, \mathrm{R}^{2}=0,04, \mathrm{~F}_{394-4}=\right.$ $7,27, \mathrm{p}<0,01)$ ve YAÖ yaşamda anlamın varlı̆̆ 1 ve ERKA rol doyumu ile PDÖ yapısal stil puanları arasındaki ilişkinin anlamlı olduğu sonucuna ulaşılmıştır. Buna göre adı geçen bu değişkenler PDÖ yapısal stil puanının toplam varyansının \%4'ünü açıklamaktadır. Standardize edilmiş beta katsayısı ve t değerleri incelendiğinde ERKA rol doyumunun anlamlı bir yordayıcı olmadığı, sadece YAÖ yaşamda anlamın varlı̆̆ının anlamlı bir yordayıcı olduğu görülmüştür. PDÖ diğer bir alt boyutu olan gelecek algısı ile bağımsız değiş̧kenlerin arasında anlamlı bir ilişki olup olmadığını belirlemek için yapılan Pearson korelasyon analizi sonucunda PDÖ gelecek algısı puanının YAÖ yaşamda anlamın aranması $(\mathrm{r}=0,19$; $\mathrm{p}<0,01)$ ve YAÖ yaşamda anlamın varlığ $(\mathrm{r}=0,23 ; \mathrm{p}<0,01)$ ile pozitif yönde anlamlı bir ilişki bulunmuştur (Bakınız Tablo 2). Bağımlı değişken ile anlamlı ilişkisi bulunan bu değişkenler regresyon analizine alınmış ve sonuçları Tablo 4'de sunulmuştur.

Tablo 4. PDÖ Gelecek Algısı Puanının Yordanmasına İlişkin Çoklu Regresyon Analiz

\begin{tabular}{cccccc}
\hline Değişken & B & Standart hata & Beta & T & p \\
\hline Sabit & 59,976 & 6,620 & & 9,060 &, 000 \\
YAÖ yaş. an. aran &, 568 &, 125 &, 210 & 4,561 &, 000 \\
YAÖ yaş. an. var & 1,345 &, 182 &, 342 & 7,391 &, 000 \\
\hline
\end{tabular}

Çoklu doğrusal regresyon analizi sonucunda anlamlı bir model ortaya çıkmış $\left(\mathrm{R}=0,32, \mathrm{R}^{2}=0,10, \mathrm{~F}_{394-4}=\right.$ $23,05, \mathrm{p}<0,001$ ) ve YAÖ yaşamda anlamın aranması ve YAÖ yaşamda anlamın varlığı ile PDÖ gelecek algısı puanı arasındaki ilişkinin anlamlı olduğu sonucuna ulaşılmıştır. Buna göre adı geçen bu değişkenler PDÖ gelecek algısı puanının toplam varyansının \%10'unu açıklamaktadır. Standardize edilmiş beta katsayısı ve $t$ değerleri incelendiğinde her iki değişkenin de anlamlı yordayıcı olduğu ve göreli önem düzeyinin sırasıyla YAÖ yaşamda anlamın varlığı, YAÖ yaşamda anlamın olduğu görülmektedir. PDÖ aile uyumu puan ile bağımsız değişkenlerin arasında anlamlı bir ilişki olup olmadığını belirlemek için yapılan Pearson korelasyon analizi sonucunda PDÖ aile uyumu puanın YAÖ yaşamda anlamın aranması $(\mathrm{r}=0,13$; $\mathrm{p}<0,05)$, YAÖ yaşamda anlamın varlığ $(\mathrm{r}=0,28 ; \mathrm{p}<0,01)$, ERKA rol doyumu $(\mathrm{r}=0,20 ; \mathrm{p}<0,01)$ ve ERKA rol dengeleme $(r=0,12 ; p<0,05)$ ile pozitif yönde anlamlı bir ilişki bulunmuştur (Bakınız Tablo 2). Bağımlı değişken ile anlamlı ilişkisi bulunan bu değişkenler regresyon analizine alınmış ve sonuçları Tablo 5'de sunulmuştur.

Tablo 5. PDÖ Aile Uyumu Puanının Yordanmasına İlişkin Çoklu Regresyon Analiz

\begin{tabular}{cccccc}
\hline Değişken & B & Standart hata & Beta & T & p \\
\hline Sabit & 9,216 & 1,709 & & 5,392 &, 000 \\
YAÖ yaş. an. aran &, 109 &, 032 &, 160 & 3,380 &, 001 \\
YAÖ yaş. an. var &, 271 &, 047 &, 276 & 5,771 &, 000 \\
ERKA rol doyumu &, 250 &, 090 &, 140 & 2,764 &, 006 \\
ERKA rol dengeleme &, 076 &, 073 &, 052 & 1,040 &, 299 \\
\hline
\end{tabular}

Çoklu doğrusal regresyon analizi sonucunda anlamlı bir model ortaya çıkmış $\left(\mathrm{R}=0,36, \mathrm{R}^{2}=0,13, \mathrm{~F}_{394-4}=\right.$ $14,74, p<0,001)$ ve YAÖ yaşamda anlamın aranması, YAÖ yaşamda anlamın varlığı, ERKA rol doyumu ve ERKA rol dengelemesi ile PDÖ aile uyumu puanı arasındaki ilişkinin anlamlı olduğu sonucuna ulaşılmıştır. Buna göre adı geçen bu değişkenler PDÖ aile uyumu puanının toplam varyansının \%13'ünü açıklamaktadır. Standardize edilmiş beta katsayısı ve t değerleri incelendiğinde ERKA rol dengelemesinin anlamlı bir yordayıcı olmadığı, yordayıcı olan diğer değişkenlerin göreli önem düzeyinin sırasıyla YAÖ yaşamda anlamın varlığ 1 , YAÖ yaşamda anlamın aranması ve ERKA rol doyumu olduğu görülmektedir. PDÖ kendilik algısı puanı ile bağımsız değişkenlerin arasında anlamlı bir ilişki olup olmadığını belirlemek için yapılan Pearson korelasyon analizi sonucunda PDÖ kendilik algısı puanının YAÖ yaşamda anlamın varlığ $(r=0,26 ; p<0,01)$, ERKA rol doyumu $(r=0,14 ; p<0,01)$ ve ERKA rol dengelemesi $(r=0,17 ; p<0,01)$ ile pozitif yönde anlamlı bir ilişki bulunmuştur (Bakınız Tablo 2). Bağımlı değişken ile anlamlı ilişkisi bulunan bu değişkenler regresyon analizine alınmış ve sonuçları Tablo 6'da sunulmuştur. 
Tablo 6. PDÖ Kendilik Algısı Puanının Yordanmasına İlişkin Çoklu Regresyon Analiz

\begin{tabular}{cccccc}
\hline Değişken & B & Standart hata & Beta & t & p \\
\hline Sabit & 13,969 & 1,430 & & 9,766 &, 000 \\
YAÖ yaş. an. var &, 218 &, 044 &, 241 & 4,992 &, 000 \\
ERKA rol doyumu &, 090 &, 085 &, 055 & 1,067 &, 287 \\
ERKA rol dengeleme &, 187 &, 069 &, 139 & 2,710 &, 007 \\
\hline
\end{tabular}

Çoklu doğrusal regresyon analizi sonucunda anlamlı bir model ortaya çıkmış $\left(\mathrm{R}=0,31, \mathrm{R}^{2}=0,09, \mathrm{~F}_{394-4}=\right.$ $13,47, \mathrm{p}<0,001)$ ve YAÖ yaşamda anlamın varlığı, ERKA rol doyumu ve ERKA rol dengelemesi ile PDÖ kendilik algısı puanı arasındaki ilişkinin anlamlı olduğu sonucuna ulaşılmıştır. Buna göre adı geçen bu değişkenler PDÖ kendilik algısı puanının toplam varyansının \%9'unu açıklamaktadır. Standardize edilmiş beta katsayısı ve t değerleri incelendiğinde ERKA rol doyumunun anlamlı bir yordayıcı olmadığı, yordayıc1 olan diğer değişkenlerin göreli önem düzeyinin sırasıyla YAÖ yaşamda anlamın varlığı ve ERKA rol dengeleme olduğu görülmektedir. PDÖ sosyal yeterlik puanı ile bağımsız değişkenlerin arasında anlamlı bir ilişki olup olmadığını belirlemek için yapılan Pearson korelasyon analizi sonucunda PDÖ sosyal yeterlik puanın YAÖ yaşamda anlamın varlığ $1(\mathrm{r}=0,29 ; \mathrm{p}<0,01)$, ERKA rol doyumu $(\mathrm{r}=0,17 ; \mathrm{p}<0,01)$ ve ERKA rol dengeleme $(r=0,10 ; p<0,05)$ ile pozitif yönde anlamlı bir ilişki bulunmuştur (Bakınız Tablo 2). Bağımlı değişken ile anlamlı ilişkisi bulunan bu değişkenler regresyon analizine alınmış ve sonuçları Tablo7'de sunulmuştur.

Tablo7. PDÖ Sosyal Yeterlilik Puanının Yordanmasına İlişkin Çoklu Regresyon Analiz

\begin{tabular}{cccccc}
\hline Değişken & B & Standart hata & Beta & t & p \\
\hline Sabit & 12,480 & 1,434 & & 8,701 &, 000 \\
YAÖ yaş. an. var &, 253 &, 044 &, 277 & 5,771 &, 000 \\
ERKA rol doyumu &, 190 &, 085 &, 115 & 2,239 &, 026 \\
ERKA rol dengeleme &, 058 &, 069 &, 043 &, 841 &, 401 \\
\hline
\end{tabular}

Çoklu doğrusal regresyon analizi sonucunda anlamlı bir model ortaya çıkmış $\left(\mathrm{R}=0,32, \mathrm{R}^{2}=0,10, \mathrm{~F}_{394-4}=\right.$ $15,34, \mathrm{p}<0,001)$ ve YAÖ yaşamda anlamın varlığı, ERKA rol doyumu ve ERKA rol dengelemesi ile PDÖ sosyal yeterlilik puanı arasındaki ilişkinin anlamlı olduğu sonucuna ulaşılmıştır. Buna göre adı geçen bu değişkenler PDÖ sosyal yeterlilik puanının toplam varyansının \%10'unu açıklamaktadır. Standardize edilmiş beta katsayısı ve $t$ değerleri incelendiğinde ERKA rol dengelemesinin anlamlı bir yordayıcı olmadı $\breve{g}$, yordayıcı olan diğer değişkenlerin göreli önem düzeyinin sırasıyla YAÖ yaşamda anlamın varlığı ve ERKA rol doyumu olduğu görülmektedir. PDÖ sosyal kaynak puanı ile bağımsız değişkenlerin arasında anlamlı bir ilişki olup olmadığını belirlemek için yapılan Pearson korelasyon analizi sonucunda PDÖ sosyal kaynak puanının YAÖ yaşamda anlamın aranması $(\mathrm{r}=0,19 ; \mathrm{p}<0,01)$, YAÖ yaşamda anlamın varlığı $(\mathrm{r}=0,26 ; \mathrm{p}<0,01)$ ve ERKA rol doyumu $(\mathrm{r}=0,16 ; \mathrm{p}<0,01)$ ile pozitif yönde anlamlı bir ilişki bulunmuştur (Bakınız Tablo 2). Bağımlı değişken ile anlamlı ilişkisi bulunan bu değişkenler regresyon analizine alınmış ve sonuçları Tablo8'de sunulmuştur.

Tablo 8. PDÖ Sosyal Kaynak Puanının Yordanmasına İlişkin Çoklu Regresyon Analiz

\begin{tabular}{cccccc}
\hline Değişken & B & Standart hata & Beta & t & p \\
\hline Sabit & 12,480 & 1,764 & & 7,073 &, 000 \\
YAÖ yaş. an. aran &, 165 &, 034 &, 227 & 4,816 &, 000 \\
YAÖ yaş. an. var &, 292 &, 050 &, 277 & 5,833 &, 000 \\
ERKA rol doyumu &, 232 &, 090 &, 122 & 2,579 &, 010 \\
\hline
\end{tabular}

Çoklu doğrusal regresyon analizi sonucunda anlamlı bir model ortaya çıkmış $\left(\mathrm{R}=0,37, \mathrm{R}^{2}=0,14, \mathrm{~F}_{394-4}=\right.$ $20,78, p<0,001)$ ve YAÖ yaşamda anlamın aranması, YAÖ yaşamda anlamın varlığı ve ERKA rol doyumu ile PDÖ sosyal kaynak puanı arasındaki ilişkinin anlamlı olduğu sonucuna ulaşılmıştır. Buna göre adı geçen bu değişkenler PDÖ sosyal kaynak puanının toplam varyansının \%14'ünü açıklamaktadır. Standardize edilmiş beta katsayısı ve $t$ değerleri incelendiğinde adı geçen tüm değişkenlerin anlamlı yordayıcılar olduğu ve değişkenlerin göreli önem düzeyinin sırasıyla YAÖ yaşamda anlamın varlığı, YAÖ yaşamda anlamın aranması ve ERKA rol doyumu olduğu görülmektedir. PDÖ toplam puan ile bağımsız değişkenlerin arasında anlamlı bir ilişki olup olmadığını belirlemek için yapılan Pearson korelasyon analizi sonucunda PDÖ toplam puanın YAÖ yaşamda anlamın aranması $(\mathrm{r}=0,17 ; \mathrm{p}<0,01)$, YAÖ yaşamda anlamın varlığ $(r=0,33 ; p<0,01)$,ERKA rol doyumu $(r=0,20 ; p<0,01)$ ve ERKA rol dengelemesi $(r=0,14 ; p<0,05)$ ile pozitif 
yönde anlamlı bir ilişki olduğu sonucuna ulaşılmıştır. Bağımlı değişken ile anlamlı ilişkisi bulunan bu değişkenler regresyon analizine alınmış ve sonuçları Tablo 9'da sunulmuştur.

Tablo9. PDÖ Toplam Puanının Yordanmasına İlişkin Çoklu Regresyon Analiz

\begin{tabular}{cccccc}
\hline Değişken & B & Standart hata & Beta & t & p \\
\hline Sabit & 59,976 & 6,620 & & 9,060 &, 000 \\
YAÖ yaş. an. aran &, 568 &, 125 &, 210 & 4,561 &, 000 \\
YAÖ yaş. an. var & 1,345 &, 182 &, 342 & 7,391 &, 000 \\
ERKA rol doyumu &, 871 &, 350 &, 122 & 2,485 &, 013 \\
ERKA rol dengeleme &, 432 &, 285 &, 074 & 1,518 &, 130 \\
\hline
\end{tabular}

Çoklu doğrusal regresyon analizi sonucunda anlamlı bir model ortaya çıkmış $\left(\mathrm{R}=0,43, \mathrm{R}^{2}=0,18, \mathrm{~F}_{394-4}=\right.$ $22,16, p<0,001)$ ve YAÖ yaşamda anlamın aranması, YAÖ yaşamda anlamın varlı̆̆ 1 , ERKA rol doyumu ve ERKA rol dengelemesi ile PDÖ toplam puan arasındaki ilişkinin anlamlı olduğu sonucuna ulaşılmıştır. Buna göre adı geçen bu değişkenler PDÖ toplam puanının toplam varyansının \%18'ini açıklamaktadır. Standardize edilmiş beta katsayısı ve $\mathrm{t}$ değerleri incelendiğinde ERKA rol dengelemesinin anlamlı bir yordayıcı olmadığı, yordayıcı olan diğer değişkenlerin göreli önem düzeyinin sırasıyla YAÖ yaşamda anlamın varlığı, YAÖ yaşamda anlamın aranması ve ERKA rol doyumu olduğu görülmektedir.

\section{TARTIŞMA ve SONUÇ}

Özel gereksinimli çocuk ebeveynlerinin yaşamda anlam düzeylerinin (YAÖ) ve ebeveyn rolüne ilişkin kendilik algılarının (ERKA) psikolojik dayanıklılıkları (PDÖ) ile ilişkisinin incelendiği araştırma sonucunda; PDÖ toplam puanın YAÖ yaşamda anlamın aranması, YAÖ yaşamda anlamın varlığı ERKA rol doyumu ile ERKA rol dengelemesi puanları arasında pozitif yönde anlamlı bir ilişki olduğu sonucuna ulaşılmıştır. Çoklu doğrusal regresyon analizi sonucunda da YAÖ yaşamda anlamın aranması, YAÖ yaşamda anlamın varlığ ilişkinin anlamlı olduğu sonucuna ulaşılmıştır. Buna göre adı geçen bu değişkenler PDÖ toplam puanının toplam varyansının \%18'ini açıklamaktadır. Analizler sonucunda ERKA rol dengelemesinin anlamlı bir yordayıcı olmadığı, yordayıcı olan diğer değişkenlerin göreli önem düzeyinin sırasıyla $Y A O ̈$ yaşamda anlamın varlı̆̆l, YAÖ yaşamda anlamın aranması ve ERKA rol doyumu olduğu görülmektedir.

Bu sonuçlar ebeveynlerin yaşamda anlam bulmalarının psikolojik dayanıklılıkları üzerinde olumlu etkisi olduğuna işaret etmektedir. Başka bir deyişle; ebeveynlerin yaşamlarında anlam aramaları ve yaşamda anlam bulmaları psikolojik dayanıklılıklarını artırabilir. Özel gereksinimli bir çocuğun varlı̆̆ ebeveynlerin yaşamına bir dolu güçlük getirirken diğer yandan yaşamlarında yeni amaçlar edinmelerine neden olabilir. Özellikle çocuklarını hayata hazırlamak ve toplumuma kazandırmak için verdikleri mücadelelerin ebeveynlere yeni yaşam amaçları kazandırdığı düşünülebilir. Yaşamda anlamın var olması için; bireyin yaşamını anlamlandırmasını sağlayan bir amacının olması ve başka insanların da yararına olacak işler yapmanın öneminden (Adler, 1997; Reker ve Woo, 2011) söz edilmektedir. Özel gereksinimli çocuk ebeveynlerinin de çocukları için birçok fedakârlıklar yaparak hatta zaman zaman özel gereksinimli çocuklarına adeta kendilerini adayarak yaşamda anlam buldukları söylenebilir. Frankl (2012) yaşamda anlam bulmak için bir insanı sevmenin öneminden söz ederken, Coutu (2002) zorluklar karşısında dayanıklılık gösteren bireylerin kötü zamanlar geçirirken gerçeği olduğu gibi kabul ederek ellerinden geleni yaptıklarını ve yaşamda anlam bulduklarından söz etmektedir. Özel gereksinimli çocuk ebeveynleri açısından bakıldığında da, anne ve baba olarak çocuğunu seven ve onun için elinden geleni yapmak için çaba gösteren ebeveynlerin özel gereksinimli çocukları aracılığıyla yaşamlarında yeni anlam arayışları ve yeni anlamlar bulmalarının onların psikolojik dayanıklılıklarının üzerinde etkili olduğu söylenebilir. Myers, Mackintosh ve Goin-Kochel (2009)'in çalışmasında; özel gereksinimli çocuk ebeveynleri tolerans, tevazu, anlama, tahammül, empati, dayanıklılık, kararlılık ve koşulsuz sevgi, sabır, eğlence gibi olumlu duyguları çocukları sayesinde kazandıklarını ifade etmişlerdir. Ayrıca ebeveynler çocuklarının kendilerini değiştirme fırsatı sağladığını, yeni bir dünyanın kapılarının aralandığını ve her şeye daha farklı bir açıdan bakabilmeyi çocuklarından öğrendiklerini belirtmişlerdir. Ebeveynlerin ifade etmiş olduğu bu tür olumlu duyguların ve farklı bakış açıları kazanmalarının hem yaşamda anlam bulmaları hem de psikolojik dayanıklılıklarını etkilediği düşünülebilir. Yaşamda anlam bulmanın olumsuz duyguları azalttığı ve bireyin kendini iyi hissetmesini sağladığı (Feldman ve Synder, 2005; Hicks ve King, 2007; Steger, Oishi ve Kashdan, 2009; Şahin, Aydın, Sarı, Kaya ve Pala, 2012; Steger ve Kashdan, 2013; Grouden ve Jose, 2015) dikkate 
alındığında, özel gereksinimli çocuk ebeveynlerinin de yaşamda anlam arayışı ve anlamın varlığı ile psikolojik olarak dayanıklı olmaları daha kolay olabilecektir.

Özel gereksinimli çocuk ebeveynlerinin ebeveyn rolüne ilişkin kendilik algıları (ERKA) ile psikolojik dayanıklıkları (PDÖ) arasındaki ilişkiye bakıldığında da; ERKA rol doyumu ve ERKA rol dengelemesi ile PDÖ toplam puan arasındaki ilişkinin anlamlı olduğu sonucuna ulaşılmıştır. Bu sonuç ebeveynlerin anne ve baba olarak rollerinden memnun olmaları ve aile içindeki rolleri dengelemelerinin onların psikolojik dayanıklılıkları üzerinde olumlu bir etkisi olduğunu göstermektedir. Ebeveynler anne ve baba olarak kendi rollerinin gereğini yaptıklarını düşündüklerinde kendilerini daha mutlu hissedebilirler. Kerpelman ve Schvaneveldt (1999)'e göre ana-babalık rolünün en önemli rol olarak algılandığı bildirilmektedir. Özel gereksinimli bir çocuğun ebeveyni olmak da çoğu ebeveyn için olumlu ve tatmin edici bir deneyim olabilir (Hyun, 2000), çünkü tüm zorluklarına karşın özel gereksinimli bir çocukla yaşamak ve gereksinimlerini karşılamak özel çaba gerektiren bir durumdur. Belsky (1984)'e göre, eğer ebeveynler çevreleri tarafindan takdir edilirlerse, ebeveynliklerine saygı duyulursa, ebeveynler duygusal olarak desteklenmiş olurlar. Toplumumuzda genellikler ebeveynler toplum içinde suçluluk, utanma vb. duygular yaşasalar da takdir edilmeleri ve özel bir çocukla yaşadıkları için anlayışla karşılandıkları görülebilmektedir. Kısaca özel gereksinimli bir çocuğun ebeveyni olarak farklı olmanın yanında özel ve kutsal hissedebilirler, bu duygular da onların rollerinden doyum almalarını ve psikolojik olarak daha dayanıklı olmalarını sağlayabilir. İlaveten günümüzde babalar da çocuklarının bakımı ve eğitiminde sorumluluk almaya (Seabra, 2007; Kuzucu, 2011) başlamışlardır. Ebeveyn, eş ve çalışan olarak kişinin elinde bulundurduğu rolleri etkili bir biçimde dengede tutması olarak tanımlanan rol dengeleme (PerryJenkins, Repetti ve Crouter, 2000), ebeveynlerin yüklerini paylaşmalarına, güçlüklerle baş edebilmelerine olanak sağlar. Dayanıkı ailelerin özelliklerine bakıldığında da, çocuklarının ihtiyaçları ile ailenin diğer bireylerinin ihtiyaçlarını dengeleyebildikleri ve buna olumlu bir anlam yükledikleri görülmüştür (Patterson 1991). Ebeveynlerin aile içindeki rollerini dengelediklerinde, hem kişisel alanlarına hem de ailevi sorumluluklarına zaman ayırmaları daha kolay olabilecektir. Bir başka deyişle ebeveyn olarak anne ve babalar hem ebeveynlik rollerini yerine getirebilir hem de birey olarak kendilerini de gerçekleştirebilirlerse, sorumluluklar da adil paylaşılabilirse ebeveynlerin psikolojik dayanıklılıkları artabilir. Diğer yandan özel gereksinimli çocuğun bakımını sürekli tek bir ebeveyn yüklendiğinde, bu sorumluluk aşırı bir yüklenmeye yol açabilir. Bu durumda çok yüklendiğini düşünen ebeveyn kendine de, eşine de öfkelenebilir, tahammülü azabilir ve sonuçta aile içi ilişkiler olumsuz etkilenebilir. Aile içi ilişkilerin olumsuz etkilenmesi ebeveynlerin psikolojik dayanıklılıklarını olumsuz etkileyebilir. Ülkemizde alan yazında yapılan araştırmalarda özel gereksinimli çocuğun bakımından çoğunlukla annelerin sorumlu olduğu (Duygun, 2001; Uğuz, Toros, İnanç ve Çolakkadığlu, 2004; Küllü, 2008) görülmektedir. Araştırma sonucundan da görülebileceği gibi annelerin fiziksel ve psikolojik yüklerini hafifletmek ve daha iyi hissetmelerini sağlamak için ebeveynler arasındaki rol dengelemenin önemi olduğu söylenebilir.

PDÖ alt boyutları ile bağımsız değişkenlerin (YAÖ ve ERKA) arasında anlamlı bir ilişki olup olmadığını belirlemek için yapılan analizler sonucunda; PDÖ yapısal stil puanı ile YAÖ yaşamda anlamın varlığı ve ERKA rol doyumu arasındaki ilişkinin anlamlı olduğu sonucuna ulaşılmış ancak ERKA rol doyumunun anlamlı bir yordayıcı olmadığı, sadece YAÖ yaşamda anlamın varlığının anlamlı bir yordayıcı olduğu görülmüştür. Yapısal stil, kişinin bir bakıma kendine güveni, güçlü tarafları ve özdisiplini gibi bireysel özelliklerinden oluşmaktadır (Çetin, Yeloğlu ve Basım, 2015). Yapılan çalışmalarda ebeveynler, özel gereksinimli bir çocuğa sahip olmalarının kişisel gelişimlerine, başka kişilerle ilişkilerine, felsefi ve ruhani değerlerine olumlu katkılar sağladığını (Scorgie ve Sobsey, 2000) ve yaşamlarını zenginleştirdiğini ifade ettikleri görülmektedir (Lawlor ve Mattingly 1998) bildirmişlerdir. Bu sonuçlar ebeveynlerin özel gereksinimli çocukları aracılığıyla kendilerine bakış açılarında ve yaşamda anlamın varlığını değerlendirmelerinde olumlu yönde etkilendikleri ve psikolojik dayanıklılıklarına katkıda bulunduğu düşünülebilir.

PDÖ diğer bir alt boyutu olan gelecek algısı ile bağımsız değişkenlerin arasında anlamlı bir ilişki olup olmadığını belirlemek için yapılan analizler sonucunda; YAÖ yaşamda anlamın aranması ve YAÖ yaşamda anlamın varlığı ile PDÖ gelecek algısı puanı arasındaki ilişkinin anlamlı olduğu sonucuna ulaşılmıştır. Her iki değişkenin de anlamlı yordayıcı olduğu ve göreli önem düzeyinin sırasıyla YAÖ yaşamda anlamın varlığı, YAÖ yaşamda anlamın olduğu görülmektedir. Gelecek algısı, olumlu bakış açısı çerçevesinde kişinin geleceğe yönelik algılarını kapsamaktadır (Çetin, Yeloğlu ve Basım, 2015). Özel gereksinimli çocuğun varlığı aile içinde birtakım inançları ve değerleri de değiştirebilir. Ebeveynlerin dünyaya bakış açıları daha gelişebilir, ebeveynler için farklı şeyler daha önemli hale gelebilir ve küçük şeylerden mutluluk duyabilirler (King, Zwaigenbaum, King, Baxter, Rosenbaum, Bates, 2006). Dünyaya 
bakış açısı değişen ebeveynlerin beklentileri ve geleceğe bakışı da değişiklik gösterecektir. Dolayısıyla hedeflerini küçülten ve küçük şeylerden mutlu olabilmeyi öğrenen ebeveynlerin yaşamlarında anlam atfettikleri unsurlar değişeceğinden psikolojik olarak da daha dayanıklı olabilmeleri mümkün olacaktır.

PDÖ alt boyutlarından aile uyumu puanı ile bağımsız değişkenlerin arasında anlamlı bir ilişki olup olmadığını belirlemek için yapılan analizler sonucunda; PDÖ aile uyumu puanın YAÖ yaşamda anlamın aranması, YAÖ yaşamda anlamın varlığı, ERKA rol doyumu ve ERKA rol dengeleme puanı arasındaki ilişkinin anlamlı olduğu sonucuna ulaşılmıştır. Analizler sonucunda ERKA rol dengelemesinin anlamlı bir yordayıcı olmadığı, yordayıcı olan diğer değişkenlerin göreli önem düzeyinin sırasıyla YAÖ yaşamda anlamın varlığı, YAÖ yaşamda anlamın aranması ve ERKA rol doyumu olduğu görülmektedir. Aile uyumu, kişinin ailesinden aldığı desteğe veya ailesi ile olan uyumuna işaret etmektedir. (Çetin, Yeloğlu ve Basım, 2015). Yapılan çalışmalarda da ebeveynlerin dayanıklılığı üzerinde yeterlik, kontrol ve uyum gibi faktörlerin koruyucu etkisi olduğu ve dayanıklılığı desteklediği bulunmuştur (Bekhet, Johnson ve Zauszniewski, 2012). Aile içinde uyumun olması aile bireylerinin kendini iyi hissetmesi ile ilişkilidir. Aile bireylerinin iyi olması, aile içinde uyumun olması öncelikle ebeveynlerin tutumu ve davranışları ile şekillenebilir. Özel gereksinimli çocuk ebeveynleri ile yapılan çalışmalarda da, ailelerin önceliklerinin ve ebeveynlerin sahip olduğu değerlerin değişiminden söz edilmektedir. Özel gereksinimli çocuğun varlığ1 ile ebeveynlerin aile bireylerinin ihtiyaçlarına daha çok dikkate almaya ve çocuklarının ihtiyaçları ile yapabildiklerine daha çok odaklanmaya başladıkları bildirilmiştir (King, Zwaigenbaum, King, Baxter, Rosenbaum, Bates, 2006). Ayrıca özel gereksinimli çocuk ebeveynleri çocuklarıyla geçirdikleri zaman ve deneyimlerin yaşamlarını zenginleştirdiğini (Lawlor ve Mattingly 1998), ailelerini daha guclu yaptığını ve birbirlerine yakınlaşmalarını sağladığını (Myers, Mackintosh, Goin-Kochel,2009) ifade etmişlerdir. Özel gereksinimli çocuklarının kendilerine kattıkları ile yaşamlarını zenginleştiren ebeveynlerin yaşamda anlam bulmalarına olanak verebilir. Diğer yandan yaşamı anlamlı gören ebeveynlerin aile içinde birbirlerini desteklemeleri, aile uyumunu sağlamaları ve zorluklara karşı daha dayanıklı olmaları mümkün olabilir.

PDÖ alt boyutlarından kendilik algısı puanı ile bağımsız değişkenlerin arasında anlamlı bir ilişki olup olmadığını belirlemek için yapılan analiziler sonucunda; PDÖ kendilik algısı puanının YAÖ yaşamda anlamın varlığı, ERKA rol doyumu ve ERKA rol dengelemesi puanı arasındaki ilişkinin anlamlı olduğu sonucuna ulaşılmıştır. Ancak ERKA rol doyumunun anlamlı bir yordayıcı olmadığı, yordayıcı olan diğer değişkenlerin göreli önem düzeyinin sırasıyla YAÖ yaşamda anlamın varlığı ve ERKA rol dengeleme olduğu görülmektedir. Kendilik algısı, öz-farkındalık ile ilişkili bir kavram olup, temelde kişinin kendisine ve kim olduğuna yönelik düşünceleri ifade etmektedir (Çetin, Yeloğlu ve Basım, 2015). Yapılan çalışmalarda da ebeveynler, özel gereksinimli bir çocuğa sahip olmalarının kişisel gelişimlerine olumlu katkılar sağladığını (Scorgie ve Sobsey, 2000) ve yaşamda neyin önemli olduğunu öğrendikleri (Lawlor ve Mattingly 1998) bildirmişlerdir. Ayrıca ebeveynler olumlu duyguları öğrendiklerini, ruhsal dünyalarının zenginleştiğini ve hayatin onlara getirdiklerini anlamlı kılmayı öğrenebildiklerini ifade etmişlerdir (Myers, Mackintosh, Goin-Kochel, 2009). Ebeveynlerin kendilerine yönelik farkındalık kazanmalarının ve çocuklarının öğrettiği olumlu tüm duyguların hem yaşamda anlamın varlığını keşfetmelerinde hem de ebeveyn olarak rollerini dengeleme de katk1 sağlayabilir. Ebeveynlerin ebeveyn olarak rollerini dengeleyebilmelerinin ve yaşamda anlamın varlığının, psikolojik dayanıklığın kendilik algısı faktöründe destekleyici etkisi olduğu söylenebilir.

PDÖ sosyal yeterlik puanı ile bağımsız değişkenlerin arasında anlamlı bir ilişki olup olmadığını belirlemek için yapılan analizler sonucunda; YAÖ yaşamda anlamın varlığı, ERKA rol doyumu ve ERKA rol dengeleme puanı arasındaki ilişkinin anlamlı olduğu sonucuna ulaşılmıştır. Ayrıca yordayıcı olan değişkenlerin göreli önem düzeyinin sırasıyla YAÖ yaşamda anlamın varlığı ve ERKA rol doyumu olduğu görülmektedir. Sosyal yeterlilik, kişilerin çevreden destek görüp görmediğiyle ilişkili bir faktördür (Çetin, Yeloğlu ve Basım, 2015). Ebeveynlik algıları ve rol dengelemeleri, sosyal destekle sağlanan doyumla da ilişkilidir (Angley, Divney, Magriples ve Kershaw, 2015). Dolayısıyla ebeveynler aile içi rollerini dengeleyebildiklerinde ve rollerinden doyum aldıklarında kendilerini daha iyi hissetmeleri mümkündür. Kendini iyi hisseden ebeveynlerin sosyal ilişkilerinin de iyi olması ve dışa dönük olma olasılıkları daha olasıdır. Başka bir deyişle sosyal destek almak ile ebeveynlik rolünden tatmin olması ve kendini iyi hissetmesi karşılıklı bir ilişki içerisindedir. Kendi içine kapanmayan, dış dünyaya kapılarını kapatmayan, olumlu duygulara sahip olan ebeveynlerin yaşamda anlam bulmaları ve hoşnut olmaları daha mümkün olacaktır. Ebeveynlerin kendi çekirdek ailesi dışında yakınlarına ve sosyal çevresine yakınlık göstermesi, sosyal çevrenin de kendilerine destek olmalarına olanak sağlayacaktır. Araştırma sonuçları da özel gereksinimli ebeveynlerinin sosyal destek almalarının güçlüklerle başa çıkmalarında, iyi hissetmelerinde ve dayanıklılıklarını arttırmada önemli rol oynadığı (White ve Hastings, 2004; Zeman ve Bulia, 2008; Weiss, Robinson, Fung, Tint, Chalmers ve Lunsky, 2013; Kırbaş ve Özkan, 2013; Lu, Yang, Skora,Wang, 
Cai,Sun ve Li, 2015 ). Kısaca ifade edilecek olursa ebeveynlik rolünden doyum almanın ve yaşamda anlam bulmanın ebeveynlerin psikolojik dayanıklılı̆̆ın sosyal yeterlik faktörü üzerinde olumlu etkisi görülmektedir.

PDÖ sosyal kaynak puanı ile bağımsız değişkenlerin arasında anlamlı bir ilişki olup olmadığını belirlemek için yapılan analizler sonucunda; YAÖ yaşamda anlamın aranması, YAÖ yaşamda anlamın varlığı ve ERKA rol doyumu puanı arasındaki ilişkinin anlamlı olduğu, adı geçen tüm değişkenlerin anlamlı yordayıcılar olduğu ve değişkenlerin göreli önem düzeyinin sırasıyla YAÖ yaşamda anlamın varlığı, YAÖ yaşamda anlamın aranması ve ERKA rol doyumu olduğu görülmektedir. Sosyal kaynaklar ise kişinin sosyal ilişkilerinin gücünü göstermektedir (Çetin, Yeloğlu ve Basım, 2015). Araştırmalarda ailelerin sosyal kaynaklara ulaşım gibi desteklere ihtiyaçları olduğu, sosyal desteğin ebeveynlerin yaşam kalitesinde ve psikolojik durumlarında olumlu etkisi olduğu belirtilmiştir (Ma, Lai ve Pun, 2002; Karadağ, 2009; Migerode, Maes, Buysse ve Brondeel, 2011). Ailenin sosyal ilişkilerinin olumsuz etkilenmesi aile bireylerinin kendi içine dönmesine neden olabilmektedir (Tokuç Öztürk, 2009). Özel gereksinimli çocuk ebeveynlerinin de öncelikle kendi rollerinden memnun olmaları, yaşamlarında anlam bulmaları kendilerine olan güvenlerini olumlu etkileyebilir. Kendisi ile barışık olan, yaşamı anlamlı bulan ebeveynlerin de sosyal kaynaklara ulaşması ile sosyal ilişkilerini kuvvetlendirerek psikolojik dayanıklılıklarına katkı sağlayabileceği söylenebilir.

$\mathrm{Bu}$ araştırmada yalnızca üç değişken kullanılmış ve ebeveynler ile çocukların özelliklerine ilişkin değişkenler araştırma kapsamında yer almamaktadır. Bu durum araştırmanın sınırlılıklarından biridir. İleride yapılacak araştırmalarda ebeveyn ve çocuklarına ilişkin farklı değişkenlere yer verilmesi ve daha geniş bir örneklem üzerinde çalışılması önerilebilir. Bu araştırmada yapıllan analizler sonucunda $Y A \ddot{O}$ yaşamda anlamın aranması, YAÖ yaşamda anlamin varliğg, ERKA rol doyumu ve ERKA rol dengelemesi ile PDÖ toplam puan arasındaki ilişkinin anlamlı olduğu sonucuna ulaşılmış ve bu değişkenlerin PDÖ toplam puanının toplam varyansının \%18'ini açıkladığı görülmüştür. Bu durum aynı zamanda varyansın geri kalan \%82'lik bir boyutunun farklı değişkenler tarafından açıklandığı anlamına da gelebilmektedir. Bu araştırmada ebeveynlerin sadece özel gereksinimli çocuk sahibi olmalarının ele alınması ve başka özelliklerinin araştırma kapsamında yer almaması da araştırmanın sınırlılıklarından biridir. . Diğer yandan ebeveynlerin çocuklarının özelliklerinin, maddi ya da sosyal destek alıp-almadıklarının ve içinde bulundukları yaşam koşullarının ele alınmamış olması da araştırmanın sınırlılıklarındandır. Masten (2001), birçok stres kaynakları ve zor yaşam durumlarına uyum sağlama sürecinde, işlevsel bir rolü bulunan kişisel temel yapıların etkili olduğunu öne sürmektedir. Çetin, Yeloğlu ve Basım (2015)'da psikolojik dayanıklılığın açıklanmasında kişiliğin önemli bir varyansa sahip olduğu bildirmişlerdir. Bu sonuçlardan yola çıkılarak ileride yapılacak araştırmalarda ebeveynlerin kişilik özelliklerinin ele alınması, beveynlerin aldıkları destek türleri ile yaşam koşullarının psikolojik dayanıklılıkları ile ilişkisinin araştırılması önerilebili 


\section{KAYNAKLAR}

Adler, A. (1997). Yaşamın anlam ve amacı. (K. Şipal,Çev.) İstanbul: Say.

Akkök, F. (1989). Özürlü bir çocuğa sahip anne-babaların kaygı ve endişe düzeyini ölçme aracının güvenirlik ve geçerlik çalışması. Psikoloji Dergisi, 23, 26-39.

Akkök, F. (2003). Bayan perşembeler ( 3.baskı). Ankara: Özgür.

Alvord, M., \& Grados, J. (2005). Enhancing resilience in children: A proactive approach. Professional Psychology: Research and Practice, 36, 238-245.

Angley, M., Divney A., Magriples U., \& Kershaw T. (2015). Social support, family functioning and parenting competence in adolescent parents. Matern Child Health J. 19(1), 67-73. doi: 10.1007/s10995-0141496-x.

Bandeira, T.T.A., \& Seidl-de-Moura, M.L. (2012). Mothers and fathers' beliefs about parental investment. Paidéia, 22(53), 355-363. doi:http://dx.doi.org/10.1590/198243272253201307

Bandura, A. (2006). Towards a psychology of human agency. Perspectives on Psychological Science, 1(2), 164-180.

Basım, N. \& Çetin, F. (2011). Yetişkinler için psikolojik dayanıklılık ölçeği’nin güvenilirlik ve geçerlilik çalışması. Türk Psikiyatri Dergisi, 22(2),104-14.

Bekhet, A. K., Johnson, N. L., \& Zauszniewski, J. A. (2012). Resilience in family members of persons with autism spectrum disorder: A review of the literature. Issues in Mental Health Nursing, 33(10), 650656.

Belsky, J. (1984). The determinants of parenting: A process model. Society for Research in Child Development, 55(1), 83-96.

Bitsika, V., Sharpley, C. F. \& Bell, R. (2013) The buffering effect of resilience upon stress, anxiety and depression in parents of a child with an autism spectrum disorder. Journal of Developmental and Physical Disabilities, 25, 533-543. doi:10,1007/s10882-013-9333-5

Bornstein, M., H., Hendricks, C., Hahn, C., Haynes, M., O., Painter, K. \& Tamis- LeMonda, C., S. (2003). Contributors to self-perceived competence, satisfaction, investment and role balance inmaternal parenting: A multivariate ecological analysis. Parenting: Science and Practice, 3(4), 285-326.

Bornstein, M.C., \& Cote, L.C. (2004). Mothers' parenting cognitions in cultures of origin, acculturating cultures, and cultures of destination. Child Development, 75(1), 221-235.

Bulut, I. (1993). Ruh hastalı̆̆ının aile işlevlerine etkisi. Başbakanlık Kadın ve Sosyal Hizmetler Müsteşarlığ

Büyüköztürk, Ş., Çakmak, E. K., Akgün, Ö. E., Karadeniz, Ş., \& Demirel, F. (2017). Bilimsel araştırma yöntemleri. Pegem Atıf İndeksi, 1-360.

Coleman, P.K., \& Karraker, K.H. (2003). Maternal self-efficacy beliefs, competence in parenting, and toddlers' behavior and developmental status. Infant Mental Health Journal, 24, 126-148.

Corwyn, R.F., \& Bradle, R.H. (1999) Determinants of paternal and maternal investment in children. Infant Mental Health Journal, 20(3), 238-256.

Coutu, D.L. (2002). How resilience Works. Harvard Business Review, 80, 46-55.

Çetin, F. , Yeloğlu, H.O., \& Basım, H.N. (2015).Ppsikolojik dayanıklılığın açıklanmasında beş faktör kişilik özelliklerinin rolü: Bir kanonik ilişki analizi. Türk Psikoloji Dergisi, 30(75), 81-92.

De Montigny, F. \& Lacharite, C. (2005). Perceived parental self-efficacy: concept analysis. Journal of Advanced Nursing, 49, 387-396.

Demirbaş, N. (2010). Yaşamda anlam ve yılmazlık. (Yayınlanmamış yüksek lisans tezi). Hacettepe Üniversitesi/Sosyal Bilimler Enstitüsü, Ankara. https://tez.yok.gov.tr/UlusalTezMerkezi/Search Tez adresinden 16 Mart 2014 tarihinde edinilmiştir.

Dereli, F. \& Okur, S. (2008). Engelli çocuğa sahip olan ailelerin depresyon durumunun belirlenmesi. Yeni Tip Dergisi, 25, 164-168.

Doğan, M. (2015). Yetersizliği olan çocuklar, aile ve aile eğitimi: Kavramsal ve uygulamaya dönük gelişmeler. Abant İzzet Baysal Üniversitesi Ë̆itim Fakültesi Dergisi, 15 (Özel Say1), 111-127.

Duarte, C.S., Bordin, I.A., Yazigi, L. \& Mooney, J. (2005). Factors associated with stress in mothers of children with autism. Autism, 9, 416-427.

Duman, H. (1995). Zihinsel engelli çocuğa sahip anne babaların kaygı düzeylerinin karşılaştırılarak çocuğa yönelik beklentilerinin belirlenmesi. (Yayınlanmamış yükssek lisans tezi). Dokuz Eylül Üniversitesi, İzmir. 
Duygun, T. (2001). Zihinsel engelli ve sağlıklı çocuk annelerinde stres belirtileri, stresle başa çıkma tarzlarl ve algılanan sosyal desteğin tükenmişlik düzeyine olan etkisi. (Yüksek lisans tezi). Ankara Üniversitesi/Sosyal Bilimler Enstitüsü, Ankara.

Earvolino-Ramirez, M. (2007). Resilience: a concept analysis. Nursing Forum, 42, 73-82.

Feldman, D.B., \& Snyder, C.R. (2005). Hope and the meaningful life: Theoritical and empirical associations between goal-directed thinking and life meaning. Journal of Social and Clinical Psychology, 24(3), 401421.

Frankl, V. E. (2012). İnsanın anlam arayışı. (S.Budak,Çev.) İstanbul: Okuyan Us.

Grouden, M. E. \& Jose, P. E. (2015). Do sources of meaning differentially predict search for meaning, presence of meaning, and wellbeing. International Journal of Wellbeing, 5(1), 33-52. doi:10.5502/ijw.v5i1.3

Güler, M., \& Yetim, Ü. (2008). Ebeveyn rolüne ilişkin kendilik algısı ölçeği: Geçerlik ve güvenirlik çalışması. Türk Psikoloji Yazıları, 1 (22), 34-43.

Harper, A., Dyches, T.T., Harper, J., Olsen Roper, S. \& South, M. (2013). Respite care, marital quality, and stress in parents of children with autism spectrum disorders. Journal of Autism and Developmental Disorders, 43(11), 2604-2614.

Hastings, R. P. \& Brown, T. (2002). Behavior problems of children with autism, parental self-efficacy and mental health. American Journal on Mental Retardation, 107(3), 222-232.

Hayden, M.F., \& Goldman, J. (1996). Families of adult with mental retardation: Stress levels and need for services. Social Work, 6, 657-68.

Hicks, J. A. \& King, L. A. (2007). Meaning in life and seeing the big picture: Positive affect and global focus. Cognition and Emotion Xp Psychology Press, 21(7), 1577-1584.

Holloway, S. D., Suzuki, S., Yamamoto, Y., \& Behrens, K. (2005). Parenting self-efficacy among Japanese mothers. Journal of Comparative Family Studies, 36 (1), 61-76.

Hoogsteen, L. R. N. \& Woodgate, R. L. (2013). Centering autism within the family : A qualitative approach to autism and the family. Journal of Pediatric Nursing, 28, 135-140.

Hyun, O. K. (2000). Parental role satisfaction among Korean mothers (I). International Journal of Human Ecology, 1 (1), 1-14.

Jones, T.L., \& Ritz, R.J. (2005). Potential roles of parental self-efficacy in parent and child adjustment: A review. Clinic Psychology, 25 (3), 341-63.

Karadağ, G. (2009). Engelli çocuğa sahip annelerin yaşadıkları güçlükler ile ailede algıladıkları sosyal destek ve umutsuzluk düzeyleri. TAF, Preventive Medicine, Bulletin, 8(4),315-322 .

Kerpelman, J.L. ve Schvaneveldt (1999). Young adults' anticipated identity importance of career, marital, and parental roles: Comparisons of men and women with different role balance orientations. Sex Roles, $41,189-217$

Kır, İ. (2011). Toplumsal bir kurum olarak ailenin işlevleri. Elektronik Sosyal Bilimler Dergisi, 10 (36), 381-404. http://www.esosder.org. Issn:1304-0278.

Kırbaş, Z. Ö., \& Özkan, H. (2013) Down sendromlu çocukların annelerinin aile işlevlerini algılama ve sosyal destek düzeylerinin değerlendirilmesi. İzmir Dr. Behçet Uz Çocuk Hastanesi Dergisi; 3(3), 171 180. doi:10.5222/buchd.2013.171

King, G. A., Zwaigenbaum, L., King, S., Baxter, D., Rosenbaum, P. \& Bates, A. (2006). A qualitative investigation of changes in the belief systems of families of children with autism or Down syndrome. Child Care Health Dev., 32(3), 353-369. doi:10.1111/j.1365-2214.2006.00571.x

Kuhlthau, K., Payakachat, N., Delahaye, J., Hurson, J., Payne, J. M., Kovacs, E., \& Tilford, J. M. (2014). Quality of life for parents of children with autism spectrum disorders. Research in Autism Spectrum Disorders, 8(10), 1339- 1350.

Kuzucu, Y. (2011). Değişen babalık rolü ve çocuk gelişimine etkisi. Türk Psikolojik Danışma ve Rehberlik Dergisi , 4 (35), 79-91.

Küçüker, S. (1993). Özürlü çocuk ailelerine yönelik psikolojik danışma hizmetleri. Ankara Üniversitesi Eğitim Bilimleri Fakültesi Özel Ĕ̈itim Dergisi, 1 (3), 23-29.

Küllü, Z. (2008). Özürlü çocuğa sahip ebeveynlerin depresyon durumunun değerlendirilmesi. (Yayımlanmamış yüksek lisans tezi). Erciyes Üniversitesi, Kayseri.

Lawlor, M. C., \& Mattingly, C. F. (1998) The complexities embedded in family-centered care. American Journal of Occupational Therapy, 52, 259-267.

Leerkes, E. M. \& Crockenberg, S. C. (2002). The development of maternal self-efficacy and its impact on maternal behavior. Infancy, 3(2), 227-247. doi: 10.1207/S15327078IN0302_7

Lu, M., Yang, G., Skora, E., Wang, G., Cai, Y., Sun, Q., \& Li, W. (2015). Self-esteem, 
social support, and life satisfaction in Chinese parents of children with autism spectrum disorder.

Research in Autism Spectrum Disorders, 17, 70-77.

Ma, J. L., Lai, K. \& Pun, S. H. (2002). Parenting distress and parental investment of Hong Kong Chinese parents with a child having an emotional or behavioural problem: A qualitative study. Child \& Family Social Work, 7 (2), 99-106.

Macias, M.M., Saylor, C.F., Rowe, B.P., \& Bell, N.L. (2003). Age-related parenting stress differences in mothers of children with spina bifida. Psychol Rep, 93,1223-1232.

MacPhee, D., Fritz, J., \& Miller-Hely, J. (1996). Ethnic variations in personal social networks and parenting. Child Development, 67, 3278-3295. doi:10.2307/1131779

Masten, A. S. (2001). Ordinary magic: Resilience processes in development. American Psychologist, 56(3), 227-238.

McConnell, D., \& Savage, A. (2015). Stress and resilience among families caring for children with 1ntellectual disability: Expanding the research agenda. Current Developmental Disorders Reports, 2, 100109. doi:10. 1007/s40474-015-0040

Migerode, F., Maes, B., Buysse, A. \& Brondeel, R. (2012). Quality of life in adolescents with a disability and their parents: the mediating role of social support and resilience. Journal of Developmental and Physical Disabilities, 24, 487-503. doi:10.1007/s10882-012-9285

Myers, B. J., Mackintosh, V. H., \& Goin-Kochel, R. P. (2009) My greatest joy and my greatest heartache:' Parents' own words on how having a child in the autism spectrum has affected their lives and their families' lives . Research in Autism Spectrum Disorders, 3, 670-684.

Noyan, F., \& Y1ld1z, D. (2006). Multilevek modeling for analyyzing education system in YTU. Journal of Engineering and Natural Sciences, 1, 34-45.

Öz, F., \& Yılmaz, B.E. (2009). Ruh sağlığının korunmasında önemli bir kavram: Psikolojik sağlamlık. Sağlık Bilimleri Fakültesi Hemşirelik Dergisi, 82-89.

Özşenol, F., Ünay, B., Aydın, H.İ., Akın, R., \& Gökçay, E. (2002). Engelli bireye sahip ailelerin beklentilerinin ve psiko-sosyal durumlarının incelenmesi. Gülhane Tip Dergisi, 44, 188-194.

Patterson, J. M. (1991). Family resilience to the challenge of a child's disability. Pediatric Annals, 20, 491-499.

Perry-Jenkins, M., Repetti, R.L., \& Crouter, A.C. (2000). Work and family in the 1990s, Journal of Marriage and the Family, 62, 981-998.

Quilan, R. J. (2007). Human parental effort and environmental risk. Proceedings of the Royal Society B: Biological Sciences, 274 (1606), 121-125. doi:10.1098/rspb.2006.3690

Reker, G. T. \& Woo, L. C. (2011). Personal meaning orientations and psychosocial adaptation in older adults. SAGE, 1(1). http://dx.doi.org/10.1177/2158244011405217

Rezendes, D.L., \& Scarpa, A. (2011). Associations between parental anxiety/depression and child behavior problems related to autism spectrum disorders: The roles of parenting stress and parenting self-efficacy. Hindawi Publishing Corporation Autism Research and Treatment, doi:10.1155/2011/395190

Rodriguez, C.M. \& Murphy, L.E. (1997). Parenting stres and abuse potential in mothers of children with developmental disabilities. Child Maltreatment, 97 (3), 245-52.

Rosemary, L.,. Hopcroft, R.L., \& Martin, D.O. (2014). The primary parental investment in children in the contemporary USA is education testing the trivers-willard hypothesis of parental investment.Human Nature, 25(2), 235-250.

Ross, K. N. (2005). Sample design for educational survey research. UNESCO.

Schieve, L.A., Blumberg, S.J., Rice, C., Visser, S.N., \& Boyle, C. (2007). The relationship between autism and parenting stress [Elektronik versiyon]. Pediatrics, 119 (1), 114-121.

Seabra, K. C. (2007). A paternidade em família urbana: Análise da participação do pai na creche-escola e nos cuidados com os fi lhos (Unpublished Ph.D. Thesis). Universidade do Estado do Rio de Janeiro, Rio de Janeiro, RJ.

Sezer, S. (2012). Yaşamın anlamı konusuna kuramsal ve psikometrik çalışmalar açısından bir bakış. Ankara Üniversitesi Eğitim Bilimleri Fakültesi Dergisi, 45 (1), 209-227.

Scorgie, K., \& Dick-Sobsey, D. (2000). Transformational outcomes associated with parenting children who have disabilities. Mental Retardation, 38(3), 195-206. doi: http://dx.doi.org/10.1352/00476765(2000)038<0195:TOAWPC $>2.0$. CO

Steger, M. F., Oishi, S., \& Kashdan, T. B. (2009). Meaning in life across the life span: Levels and correlates of meaning in life from emerging adulthood to older adulthood. The Journal of Positive Psychology, 4 (1), 43-52.http://dx.doi.org/10.1080/17439760802303127 
Steger, M. F., \& Kashdan, T. B. (2013). The unbearable lightness of meaning: Well-being and unstable meaning in.The Journal of Positive Psychology, 8(2), 103-115. doi: 10.1080/17439760.2013.771208

Şahin, M., Aydın,B., Sarı, S.V., Kaya, S. \& Pala, H. (2012). Öznel iyi oluşu açıklamada umut ve yaşamda anlamın rolü. Kastamonu Ë̆itim Dergisi, 20 (3), 827-836.

Terzi, Ş. (2008). Üniversite öğrencilerinin psikolojik dayanıklılıkları ile algıladıkları sosyal destek arasındaki ilişki. Türk Psikolojik Danışma ve Rehberlik Dergisi, 3 (29), 1-11.

Tokuç Öztürk, F. (2009) Otistik Çocuk Ve Aile Özelliklerinin Aile İşlevlerine Etkisi. (Yüksek Lisan Tezi) Marmara Üniversitesi Sağlı Bilimleri Enstitüsü

Toros, F. (2002). Zihinsel ve/veya bedensel engelli çocukların annelerinin anksiyete, depresyon, evlilik uyumunun ve çocuğu algılama şeklinin değerlendirilmesi. Psikiyatri Dergisi, 3, 45-52.

Tusaie, K. \& Dyer, J. (2004). Resilience: A historical review of the construct. Holistic Nursing Practice, 18 (1), 3-8.

Uğuz, Ş., Toros, F., İnanç, B. Y., \& Çolakkadıoğlu, O. (2004). Zihinsel ve/veya bedensel engelli çocukların annelerinin anksiyete, depresyon ve stres düzeylerinin belirlenmesi. Klinik Psikiyatri, 7, 42-47.

Wagnild, G.M., Young, H.M. (1993). Development and psychometric evaluation of the resilience scale. $J$ Nurs Meas, 1, 165-178.

Weaver, C. M., Shaw, D. S., Dishion, T. J., \& Wilson, M. N. (2008). Parenting self- efficacy and problem behavior in children at high risk for early conduct problems: The mediating role of maternal depression. Infant Behavior \& Development, 31 (4), 594-605. doi:10.1016/j.infbeh.2008.07.006

Weiss, J. A., Robinson, S., Fung, S., Tint, A., Chalmers, P., \& Lunsky, Y. (2013). Family hardiness, social support, and perceived self-efficacy in mothers of children with autism spectrum disorders. Research in Autism Spectrum Disorders, 7, 1310-1317.

White, N., \& Hastings, R. (2004). Social and professional support for parents of adolescents with severe intellectual disabilities, Journal of Applied Research in Intellectual Disabilities, 17, 181-190.

Yalom, I. (2001). Varoluşçu psikoterapi. İyidoğan Babayiğit, Z. (Çev.). İstanbul: Kabalcı.

Yeung, W. J., Miriam R. Linver, M.R., \& Brooks-Gunn, J. (2002). How money matters for young children's development: Parental investment and family processes. Child Development, 73 (6), 1861-1879.

Zeman, L. D., \& Bulia, S. (2008). Practice wisdom on custodial parenting with mental illness: A strengths view. Journal of Family Social Work, 10(3), 51-65. 